\title{
PENGARUH KOMPETENSI, INDEPENDENSI, DAN PROFESIONALISME AUDITOR TERHADAP KUALITAS AUDIT DENGAN ETIKA AUDITOR SEBAGAI VARIABEL MODERASI
}

\author{
Sri Rahayu Indah Azhari \\ Universitas Muslim Indonesia \\ Email: srirahayuindahazhari@hmail.com \\ Asriani Junaid \\ Universitas Muslim Indonesia \\ Email: asrianijunaid@umi.ac.id \\ Julianty Sidik Tjan \\ Universitas Muslim Indonesia \\ Email: juliantysidiktjan@umi.ac.id
}

\begin{abstract}
The aim of this research is to analyse the influence of competence, independence, and professionalism on audit quality. It also analyses how the auditor ethics can moderate those independent variables to dependent variable. This research carried out on the representative of Badan Pengawasan Keuangan dan Pembangunan (BPKP) of West Sulawesi Province with 75 auditors as the respondent. The study used questionnaire as the data collecting method. Then it analysed by using multiple regression analyses dan moderated regression analysis (MRA). The results of the reseach showed that competence, independence, and professionalism effect significantly the audit quality. Auditor ethics is able to moderate the influence of competence and independence to audit quality. Auditor ethics is unable to moderate the influence of professionalism to audit quality.
\end{abstract}

Keyword: Competence, Independence, Professionalism, Audit Quality and Auditor Ethics

\begin{abstract}
Abstrak
Tujuan dari penelitian ini adalah untuk mengetahui pengaruh kompetensi, independensi dan profesionalisme terhadap kualitas audit. Kemudian untuk mengetahui apakah etika auditor dapat memoderasi hubungan antara kompetensi, independensi dan profesionalisme dengan kualitas audit. Penelitian ini dilakukan di Perwakilan BPKP Provinsi Sulawesi Barat dengan sampel auditor sebanyak 75 orang. Metode pengumpulan data adalah dengan menggunakan daftar kuesioner. Sedangkan metode analisis data dengan menggunakan analisis regresi linear berganda dan Moderated Regression Analysis (MRA). Hasil penelitian menemukan bahwa kompetensi, independensi dan profesionalisme berpengaruh signifikan terhadap kualitas audit. Etika auditor dapat memperkuat hubungan antara kompetensi dan independensi dengan kualitas audit. Kemudian etika auditor tidak dapat memperkuat hubungan antara profesionalisme dengan kualitas audit.
\end{abstract}

Kata kunci: Kompetensi, Independensi, Profesionalisme, Kualitas Audit dan Etika Auditor 
Invoice: Jurnal Ilmu Akuntansi

p-ISSN: 2714-6359 e-ISSN: 2714-6340

Vol.2 Nomor 2 September 2020

\section{PENDAhUluaN}

Setiap entitas pemerintahan wajib menyampaikan laporan pertanggungjawaban berupa laporan keuangan selama satu periode. Sebagaimana diamanatkan dalam Pembukaan Undang-Undang Dasar Negara Republik Indonesia Tahun 1945 bahwa keuangan negara merupakan salah satu unsur pokok dalam penyelenggaraan pemerintahan negara dan mempunyai manfaat yang sangat penting guna mewujudkan tujuan negara untuk mencapai masyarakat yang adil, makmur, dan sejahtera (Peraturan Badan Pemeriksa Keuangan RI UU No. 15 Tahun 2006). Untuk tercapainya tujuan negara tersebut, pengelolaan dan tanggung jawab keuangan negara memerlukan suatu lembaga pengawasan yang bebas, mandiri, dan profesional untuk menciptakan pemerintahan yang bersih dan bebas dari korupsi, kolusi, dan nepotisme. Berdasarkan Peraturan Presiden Nomor 192 Tahun 2014, Badan Pengawasan Keuangan dan Pembangunan (BPKP) merupakan suatu institusi yang dipercaya dapat mewujudkan tata kelola keuangan negara yang baik, transparan, dan akuntabel (good governance).

Akuntabilitas sektor publik berhubungan dengan praktik transparansi dan pemberian informasi kepada publik dalam rangka pemenuhan hak publik. Sedangkan good governance menurut Bank dunia (World Bank) didefinisikan sebagai suatu penyelenggaraan manajeman pembangunan yang solid dan bertanggung jawab dan sejalan dengan prinsip demokrasi dan pasar yang efisien, penghindaran salah alokasi dana investasi, pencegahan korupsi baik secara politis maupun administra menciptakan disiplin anggaran, serta menciptakan kerangka hukum dan politik bagi tumbuhnya aktivitas usaha (Mardiasmo, 2002:17).

Ikatan Akuntan Indonesia (IAI) menyatakan bahwa audit yang dilakukan auditor dikatakan berkualitas, jika memenuhi standar auditing dan standar pengendalian mutu. Kriteria mutu profesional auditor seperti yang diatur oleh standar umum auditing meliputi independensi, integritas dan objektivitas. De Angelo (1981:186) mendefinisikan result quality of audit (kualitas hasil audit) sebagai kemungkinan (probability) dimana seorang auditor menemukan dan melaporkan tentang adanya suatu pelanggaran dalam sistem akuntansi kliennya. Kemungkinan penemuan suatu pelanggaran tergantung pada kemampuan teknikal auditor dan independensi auditor tersebut.

Penelitian yang dilakukan oleh Parasayu (2014), ada lima faktor yang dapat mempengaruhi kualitas hasil audit yaitu, (1) obyektifitas, bebasnya seseorang dari pengaruh pandangan subyektif pihak- pihak lain yang berkepentingan, sehingga dapat mengemukakan pendapat menurut apa adanya, (2) kompetensi, keahlian seorang auditor meliputi pengalaman dan pendidikan, (3) pengetahuan auditor tentang audit, mengetahui secara keseluruhan proses audit dan standart audit, (4) integritas, dapat menerima kesalahan yang tidak disengaja dan perbedaan pendapat yang jujur, tetapi tidak dapat menerima kecurangan prinsip, (5) etika profesi, nilai tingkah laku atau aturan-aturan tingkah laku yang diterima dan digunakan oleh suatu golongan tertentu atau individu. Menurut Kristanti (2013:1), kurangnya kompetensi auditor menyebabkan kasus- 
kasus kecurangan pada objek audit sering terjadi. Maka BPKP sebagai badan pemeriksa lembaga yang menggunakan dana dari pemerintah harusnya lebih teliti dan kompeten lagi dalam mengaudit atas berbagai bentuk laporan yang diaudit.

Berdasarkan fenomena, auditor BPKP yang merupakan auditor internal pemerintah memiliki posisi yang rentan terhadap tekanan politik. Kadang intervensi politik bisa terjadi jika temuan terkait sampai dengan ranah politik. Irma (2018) mengemukakan peran auditor sangat besar dalam pemberantasan korupsi yang pada akhirnya membawa harapan dan resiko bagi auditor itu sendiri. Dengan kata lain profesi auditor seperti pedang bermata dua. Disatu sisi diharapkan terciptanya tata pemerintahan yang baik/ good public governance. Di sisi lain resiko yang harus dihadapi baik resiko yang berbahaya misal tekanan dari pihak auditee, ancaman dengan psikis maupun resiko yang "tidak berbahaya" misal pemberian uang dari auditee walau dengan alasan uang makan, uang transport dan lain - lain. Namun, seharusnya resiko tersebut baik yang berbahaya maupun yang "tidak berbahaya" tidak mempengaruhi independensi auditor dalam membuat keputusan (Wulandari, 2011). Pemahaman akan pentingnya audit yang berkualitas bagi terwujudnya pemerintahan yang akuntabel akan membuat BPKP Perwakilan Sulawesi Barat harus lebih objektif lagi dalam praktiknya serta meningkatkan kompetensi, independensi dan profesionalisme yang dimilikinya.

Teori keagenan yang dikembangkan oleh Jensen dan Meckling (1976) mengemukakan adanya konflik kepentingan antara manajemen selaku agen dan pemilik serta entitas lain dalam kontrak (misal kreditur) selaku principal. Principal ingin mengetahui segala informasi termasuki aktivitas manajemen, yang terkait dengan investasi atau dananya dalam perusahaan. Hal ini dilakukan dengan meminta laporan pertanggungjawaban dari agen (manajemen). Berdasarkan laporan tersebut, principal dapat menilai kinerja manajemen. Namun yang seringkali terjadi adalah kecenderungan manajemen untuk melakukan tindakan yang membuat laporannya kelihatan baik, sehingga kinerjanya dianggap baik. Untuk mengurangi atau meminimalkan kecurangan yang dilakukan oleh manajemen dan membuat laporan keuangan yang dibuat manajemen lebih dapat dipercaya (reliabel) maka diperlukan pengujian dan dalam hal itu pengujian tersebut hanya dapat dilakukan oleh pihak ketiga yang independen yaitu auditor independen.

Teori sikap dan perilaku (theory of attitudes and behavior) dikembangkan oleh Triandis (1980) yang menyatakan bahwa perilaku ditentukan oleh apa yang orang-orang ingin lakukan (sikap), apa yang mereka pikirkan akan mereka lakukan (aturan-aturan sosial), apa yang mereka biasa lakukan (kebiasaan) dan dengan konsekuensi perilaku yang mereka pikirkan. Seorang auditor profesional akan bertindak sesuai dengan peraturan dan standar profesinya dalam melaksanakan audit sehingga menghasilkan kualitas audit yang baik.

Kualitas audit sebagai Proses untuk memastikan bahwa standar auditingnya berlaku umum diikuti oleh setiap audit, mengikuti prosedur pengendalian kualitas khusus membantu 
memenuhi standar-standar secara konsisten dalam penugasannya hingga tercapai kualitas hasil yang baik (Arens, 2011:47). Kualitas audit didefinisikan sebagai probabilitas bahwa auditor akan baik dan benar menemukan laporan kesalahan material, keliru, atau kelalaian dalamlaporan materi keuangan klien. Probabilitas auditor untuk melaporkan penyelewengan yang terjadi dalam sistem akuntansi klien tergantung pada independensi auditor.

Agoes (2013:146), kompetensi adalah suatu kecakapan dan kemampuan dalam menjalankan suatu pekerjaan atau profesinya. Kompetensi sebagai keharusan bagi auditor untuk memiliki pendidikan formal dibidang auditing dan akuntansi, pengalaman praktik yang memadai bagi pekerjaan yang sedang dilakukan, serta mengikuti pendidikan profesi yang berkelanjutan (Arens et. al. 2013:42).

Namun sesuai dengan tanggungjawabnya untuk menaikkan tingkat keandalan laporan keuangan suatu perusahaan maka akuntan publik tidak hanya perlu memiliki kompetensi atau keahlian saja tetapi juga harus independen dalam pengauditan.

Mulyadi (2010:87) menjelaskan bahwa Independensi adalah sikap mental yang bebas dari pengaruh, tidak dikendalikan oleh pihak lain, tidak tergantung pada orang lain. Independensi juga berarti adanya kejujuran dalam diri auditor dalam mempertimbangkan fakta dan adanya pertimbangan yang objektif tidak memihak dalam diri auditor dalam memuaskan dan menyatakan pendapatnya.

Profesionalisme juga menjadi syarat utama bagi seseorang yang ingin menjadi seorang auditor eksternal. Sebab dengan profesionalisme yang tinggi kebebasan auditor akan semakin terjamin. Untuk menjalankan perannya yang menuntut tanggung jawab yang semakin luas, auditor eksternal harus memiliki wawasan yang luas tentang kompleksitas organisasi modern.

Kompetensi, independensi, dan profesionalisme yang dimiliki auditor dalam penerapannya akan terkait dengan etika. Ludigdo et.al. (2001) mendefinisikan etika sebagai seperangkat aturan atau norma atau pedoman yang mengatur perilaku manusia, baik yang harus dilakukan maupun yang harus ditinggalkan yang dianut oleh sekelompok atau segolongan manusia atau masyarakat atau profesi. Akuntan mempunyai kewajiban untuk menjaga standar perilaku etis tertinggi mereka kepada organisasi dimana mereka bernaung, profesi mereka, masyarakat dan diri mereka sendiri dimana akuntan mempunyai tanggung jawab menjadi komponen dan untuk menjaga integritas dan objektivitas mereka (Nugrahaningsih, 2005).

Najib (2013), melakukan penelitian berjudul Pengaruh Keahlian, Independensi, dan Etika Terhadap Kualitas Audit menunjukkan bahwa Keahlian, Independensi, dan Etika tidak berpengaruh secara bersama-sama terhadap Kualitas Audit. Independensi dan Etika yang berpengaruh secara signifikan terhadap Kualitas Audit, sedangkan Keahlian tidak ikut berperan didalamnya.

Samsi et.al. (2013) dalam penelitiannya berjudul Pengaruh Pengalaman Kerja, Independensi, dan Kompetensi terhadap Kualitas Audit: Etika Auditor sebagai Variabel Pemoderasi menunjukkan bahwa variabel Pengalaman Kerja berpengaruh 
negatif terhadap Kualitas Audit. Variabel Independensi menunjukkan pengaruh positif terhadap Kualitas Audit. Variabel Kompetensi tidak berpengaruh terhadap Kualitas Audit. Interaksi Pengalaman Kerja dan Kepatuhan Etika Auditor terhadap Kualitas Audit berpengaruh positif.

Harahap (2015), melakukan penelitian pada kantor BPKP Perwakilan Daerah Istimewa Yogyakarta mengenai Pengaruh kompetensi, independensi, objektivitas dan sensitivitas etika profesi terhadap kualitas hasil audit. Variabel independen yang digunakan adalah kompetensi, independensi, objektivitas dan sensitivitas etika profesi auditor sedangkan variabel dependennya adalah kualitas audit. Dari hasil penelitian ini ditemukan bahwa kompetensi, independensi, objektivitas dan sensitivitas etika profesi auditor memiliki pengaruh positif terhadap kualitas audit.

Terkait dengan konteks inilah, muncul pertanyaan seberapa tinggi tingkat Kompetensi, independensi dan profesionalisme auditor saat ini dan apakah kompetensi, independensi dan profesionalisme auditor tersebut berpengaruh terhadap kualitas audit yang dihasilkan oleh akuntan publik. Kualitas audit ini penting karena dengan kualitas audit yang tinggi maka akan dihasilkan laporan keuangan yang dapat dipercaya sebagai dasar pengambilan keputusan. Selain itu adanya kekhawatiran akan merebaknya skandal keuangan, dapat mengikis kepercayaan publik terhadap laporan keuangan auditan dan profesi akuntan publik.

Penelitian ini mengacu kepada penelitian yang dilakukan oleh Ujianti Tawakkal et. al (2019) yang membahas masalah Pengaruh Independensi Auditor
Terhadap Kualitas Hasil Audit Pada

Kantor Inspektorat Provinsi Sulawesi Selatan. Yang membedakan penelitian ini dengan penelitian sebelumnya yaitu pada penelitian ini menambahkan dua variabel independen yaitu kompetensi dan profesionalisme kemudian etika auditor sebagai variabel moderasi.

Mengingat pentingnya peran

Perwakilan Badan Pengawasan Keuangan dan Pembangunan dalam kelangsungan pemerintah, maka dilakukan penelitian mengenai kualitas audit yang berada didalamnya. Peneliti mengangkat judul "Pengaruh Kompetensi, Independensi, Dan Profesionalisme Auditor Terhadap Kualitas Audit Dengan Etika Auditor Sebagai Variabel Moderasi (Studi Kasus pada Auditor Perwakilan Badan Pengawasan Keuangan dan Pembangunan Provinsi Sulawesi Barat)."

\section{TINJAUAN PUSTAKA}

\subsection{Audit}

\section{a. Pengertian Audit}

Arens et.al. (2011;4) auditing adalah proses pengumpulan dan evaluasi bukti tentang informasi untuk menentukan dan melaporkan derajat kesesuaian antara informasi itu dan kriteria yang telah ditetapkan. Auditing harus dilakukan oleh orang yang kompeten dan independen.

Agoes (2014:4) audit yaitu Suatu pemeriksaan yang dilakukan secara kritis dan sistematis, oleh pihak yang independen, terhadap laporan keuangan yang telah disusun oleh manajemen, beserta catatan-catatan pembukuan dan bukti-bukti pendukungnya, dengan tujuan untuk memberikan pendapat mengenai kewajaran laporan keuangan tersebut. 
Audit merupakan suatu tindakan yang membandingkan antara fakta atau keadaan sebenarnya (kondisi) dengan keadaan yang seharusnya ada. Pada dasarnya audit bertujuan untuk menilai apakah pelaksanaan yang dilakukan telah sesuai dengan apa yang telah ditetapkan dan untuk menilai atau melihat apakah yang ada telah sesuai dengan apa yang diharapkan.

Dari beberapa definisi diatas dapat diambil kesimpulan bahwa audit adalah suatu proses yang sistematik dalam hal memeriksa beberapa kegiatan tertentu untuk mengumpulkan dan menilai suatu bukti apakah sudah memiliki tingkat kesesuaian dengan kriteria yang telah ditetapkan serta menyampaikan hasilnya kepada pihak yang berkepentingan.

\section{b. Tujuan Audit}

Tujuan umum audit adalah untuk menyatakan pendapat atas kewajaran, dalam semua hal yang material posisi keuangan dan hasil usaha serta arus kas sesuai dengan prinsip akuntansi yang berlaku umum. Untuk mencapai tujuan ini auditor perlu menghimpun bukti kompeten yang cukup, auditor perlu mengidentifikasikan dan menyusun sejumlah tujuan audit spesifik untuk setiap akun laporan keuangan.

Berdasarkan Standar Profesional Akuntansi Publik (2001) Tujuan audit atas laporan keuangan oleh auditor independen pada umumnya adalah untuk menyatakan pendapat tentang kewajaran, dalam semua hal material, posisi keuangan, hasil usaha, perubahan entitas, dan arus kas sesuai dengan prinsip akuntansi yang berlaku umum di indonesia (SA seksi 110).

\section{c. Jenis-jenis Audit}

Pengauditan dapat dibagi dalam beberapa jenis. Pembagian ini dimaksudkan untuk menentukan tujuan atau sasaran yang ingin dicapai dengan adanya pengauditan tersebut. Dibawah ini akan di paparkan jenis audit menurut ahli. Arens et.al. (2012:16), Akuntan Publik melakukan tiga jenis utama aktivitas audit. Ketiga jenis aktivitas audit tersebut adalah sebagai berikut:

1) Audit Operasional

Audit operasional mengevaluasi efisiensi dan efektivitas setiap bagian dari prosedur dan metode operasi organisasi. Pada akhir audit operasional, manajemen biasanya mengharapkan saran-saran untuk memperbaiki operasi. Dalam audit operasional, review atau penelaahan yang dilakukan tidak terbatas pada akuntansi, tetapi dapat mencakup evaluasi atas struktur organisasi, operasi komputer, metode produksi, pemasaran dan semua bidang lain dimana auditor menguasainya.

2) Audit Ketaatan

Audit ketaatan dilaksanakan untuk menentukan apakah pihak yang diaudit telah mengikuti prosedur, aturan, atau ketentuan tertentu yang diterapkan oleh otoritas yang lebih tinggi.

3) Audit Laporan Keuangan.

Audit laporan keuangan dilakukan untuk menentukan apakah laporan keuangan (informasi yang diverifikasi) telah dinyatakan sesuai dengan kriteria tertentu. Biasanya, kriteria yang berlaku adalah prinsip-prinsip akuntansi yang berlaku umum.

\section{d. Jenis-jenis Auditor}

Arens et.al. (2012) yang dialih bahasakan Jusuf (2012:19) auditor yang paling umum terdiri dari empat jenis yaitu:

1) Auditor Independen (Akuntan Publik) Auditor independen berasal dari Kantor Akuntan Publik (KAP) 
bertanggung jawab mengaudit laporan keuangan historis yang dipublikasikan oleh perusahaan. Oleh karena luasnya penggunaan laporan keuangan yang telah diaudit dalam perekonomian indonesia, serta keakraban para pelaku bisnis dan pemakai lainnya, sudah lazim digunakan istilah auditor dan kantor akuntan publik dengan pengertian yang sama, meskipun ada beberapa jenis auditor. KAP sering kali disebut auditor eksternal atau auditor independen untuk membedakannya dengan auditor internal.

2) Auditor Pemerintah

Auditor Pemerintah merupakan auditor yang berasal dari lembaga pemeriksa pemerintah. Di Indonesia, lembaga yang bertanggung jawab secara fungsional atau pengawasan terhadap kekayaan dan keuangan negara adalah Badan Pemeriksa Keuangan (BPK) sebagai lembaga tertinggi, Badan Pegawasan Keuangan dan Pembangunan (BPKP), dan Inspektorat Jendral (Itjen) yang ada pada departemen-departemen pemerintah. BPK mengaudit sebagian besar informasi keuangan yang dibuat oleh berbagai macam badan pemerintah baik pusat maupun daerah sebelum diserahkan kepada DPR. BPKP mengevaluasi efisiensi dan efektivitas operasional berbagai program pemerintah. Sedangkan Itjen melaksanakan pengawasan terhadap pelaksanaan tugas di lingkungan departemen atau kementriannya.

3) Auditor Pajak

Auditor Pajak berasal dari Direktorat Jendral (Ditjen) Pajak bertanggung jawab untuk memberlakukan peraturan pajak. Salah satu tanggung jawab utama Ditjen Pajak adalah mengaudit Surat Pemberitahuan (SPT) wajib pajak utuk menentukan apakah SPT itu sudah mematuhi peraturan pajak yang berlaku. Audit ini murni audit ketaatan. Auditor yang melakukan pemeriksaan ini disebut auditor pajak.

4) Auditor Internal (Internal Auditor)

Auditor internal dipekerjakan oleh perusahaan untuk melakukan audit bagi manajemen. Tanggung jawab auditor internal sangat beragam, tergantung pada yang mempekerjakan mereka. Akan tetapi, auditor internal tidak dapat sepenuhnya Independen dari entitas tersebut selama masih ada hubungan antara pemberi kerja-karyawan. Para pemakai dari luar entitas mungkin tidak ingin mengandalkan informasi yang hanya diverifikasi oleh auditor internal karena tidak adanya independensi. Ketiadaan independensi ini merupakan perbedaan utama antara auditor internal dan KAP.

\subsection{Kompetensi}

\section{a. Pengertian Kompetensi}

Standar umum pertama (SA seksi 210 dalam SPAP 2011) menyebutkan bahwa audit harus dilaksanakan oleh seorang atau lebih yang memiliki keahlian dan pelatihan teknis yang cukup sebagai auditor. Agoes (2013:146) kompetensi adalah Suatu kecakapan dan kemampuan dalam menjalankan suatu pekerjaan atau profesinya. Orang yang kompeten berarti orang yang dapat menjalankan pekerjaannya dengan kualitas hasil yang baik. Dalam arti luas kompetensi mencakup penguasaan ilmu/pengetahuan (knowledge), dan keterampilan (skill) yang mencukupi, serta mempunyai sikap dan perilaku (attitude) yang sesuai untuk melaksanakan pekerjaan atau profesinya. Arens et.al. (2013:42) kompetensi sebagai keharusan bagi auditor untuk 
memiliki pendidikan formal dibidang auditing dan akuntansi, pengalaman praktik yang memadai bagi pekerjaan yang sedang dilakukan, serta mengikuti pendidikan profesi yang berkelanjutan. Pengertian kompetensi ini pada prinsipnya sama dengan yang didefenisikan Robbin dalam Cristiawan (2011:38) bahwa kompetensi adalah Kemampuan (ability) atau kapasitas seseorang untuk mengerjakan berbagai tugas dalam suatu pekerjaan, dimana kemampuan ini ditentukan oleh 2 (Dua) faktor yaitu kemampuan intelektual dan kemampuan fisik.

Secara lebih rinci, Spencer dalam Harhianto (2012:84) mengemukakan bahwa kompetensi menunjukan karakteristik yang mendasari perilaku yang menggambarkan motif, karakteristik pribadi (ciri khas), konsep diri, nilai-nilai, pengetahuan atau keahlian yang dibawa seseorang yang berkinerja unggul (superior performer) di tempat kerja. Ada 5 (lima) karakteristik yang membentuk kompetensi yakni:

1) Faktor pengetahuan meliputi masalah teknis, administratif, proses kemanusiaan, dan sistem.

2) Keterampilan, merujuk pada kemampuan sesorang untuk melakuakn suatu kegiatan.

3) Konsep diri dan nilai-nilai, merujuk pada sikap, nilai-nilai dan citra diri seseorang, seperti kepercayaan seseorang bahwa dia bisa berhasil dalam suatu situasi.

4) Karakteristik pribadi, merujuk pada karakteristik fisik dan konsistensi tanggapan terhadap situasi atau informasi, seperti pengendalian diri dan kemampuan untuk tetap tenang dibawah tekanan.

5) Motif, merupakan emosi, hasrat, kebutuhan psikologi atau dorongandorongan lain yang memicu tindakan.

Peraturan Pemerintah (PP) No. 23 Tahun 2004, tentang Badan Nasional Sertifikasi Profesi (BNSP) menjelaskan tentang sertifikasi kompetensi kerja sebagai suatu proses pemberian sertifikat kompetensi yang dilakukan secara sistematis dan objektif melalui uji kompetensi yang mengacu kepada standar kompetensi kerja nasional Indonesia dan atau Internasional. Keputusan Kepala Badan Kepegawaian Negeri Nomor: 46A tahun 2003, tentang pengertian kompetensi adalah Kemampuan dan karakteristik yang dimiliki oleh seorang pegawai Negeri Sipil berupa pengetahuan, keterampilan, dan sikap perilaku yang diperlukan dalam pelaksanaan tugas jabatan, sehingga pegawai Negeri Sipil tersebut dapat melaksanakan tugasnya secara profesional, efektif, dan efisien.

Dari uraian pengertian diatas dapat ditarik kesimpulan bahwa kompetensi yaitu sifat dasar yang dimiliki atau bagian kepribadian yang mendalam dan melekat kepada seseorang serta prilaku yang dapat diprediksi pada berbagai keadaan dan tugas pekerjaan sebagai dorongan untuk mempunyai prestasi dan keinginan berusaha agar melaksanakan tugas dengan efektif.

Ketidaksesuaian dalam kompetensi-kompetensi inilah yang membedakan seorang pelaku unggul dari pelaku yang berprestasi terbatas. Kompetensi terbatas dan kompetensi istimewa untuk suatu pekerjaan tertentu merupakan pola atau pedoman dalam pemilihan karyawan (personal selction), perencanaan pengalihan tugas (succesion palnning), penilaian kerja (performance 
Invoice: Jurnal Ilmu Akuntansi

p-ISSN: 2714-6359 e-ISSN: 2714-6340

Vol.2 Nomor 2 September 2020

$\begin{aligned} & \text { appraisal) dan pengembangan } \\ & \text { (development). }\end{aligned}$

\section{b. Standar Kompetensi}

Menurut Peraturan Kepala Badan

Pengawasan Keuangan dan

Pembangunan (BPKP, 2007) yang

dimaksud dengan kompetensi:

1) Auditor

Auditor adalah jabatan yang mempunyai ruang lingkup, tugas, tanggung jawab, dan wewenang untuk melakukan pengawasan intern pada instansi pemerintah, lembaga atau pihak lain yang didalamnya terdapat kepentingan Negara sesuai dengan peraturan perundang-undangan, yang didukung oleh pegawai Negeri sipil dengan hak dan kewajiban yang diberikan secara penuh oleh pejabat yang berwenang.

2) Aparat pengawas Intern Pemerintah (APIP)

$$
\text { Aparat Pengawas Intern }
$$

Pemerintah (APIP) adalah instansi pemerintah yang dibentuk dengan tugas melaksanakan pengawasan intern di lingkungan pemerintah pusat atau pemerintah daerah, yang terdiri dari Badan Pengawasan intern pada kesekretariatan Lembaga Tinggi Negara dan Lembaga Negara, Inspektorat Provinsi/Kabupaten/Kota, dan unit pengawasan intern pada Badan Hukum lainnya sesuai dengan peraturan perundang-undangan.

3) Kompetensi

Kompetensi adalah sipil berupa kemampuan karakteristik yang dimiliki oleh seorang Pegawai Negeri Sipil berupa pengetahuan, keahlian, dan sikap yang diperlukan dalam pelaksanaan tugas jabatannya.

4) Standar Kompetensi
Standar Kompetensi Auditor

adalah ukuran kemampuan minimal yang harus dimiliki auditor mencakup aspek pengetahuan (knowledge), keterampilan/keahlian (skill), dan sikap prilaku (attitude) untuk melakukan tugas-tugas dalam Jabatan Fungsional Auditor dengan hasil baik.

5) Kompetensi Umum

Kompetensi umum adalah kompetensi yang berkaitan dengan persyaratan umum untuk dapat diangkat sebagai auditor.

6) Kompetensi teknis pengawasan

Kompetensi teknis pengawasan adalah kompetensi yang terkait dengan persyaratan untuk dapat melaksanakan penugasan sesuai dengan jenjang jabatannya.

7) Prinsip-prinsip dasar Standar Kompetensi Auditor

Prinsip-prinsip dasar standar kompetensi auditor adalah asumsiasumsi dasar, prinsip-prinsip yang diterima secara umum, dan persyaratan yang digunakan dalam mengembangkan kompetensi auditor sesuai dengan jenjang jabatannya.

8) Standar Kompetensi Auditor Terampil

Standar kompetensi auditor terampil adalah standar kompetensi yang harus dimiliki oleh seseorang yang menduduki jabatan pelaksanaan, auditor pelaksana lanjutan.

9) Standar Kompetensi Auditor Ahli

Standar kompetensi auditor ahli adalah standar kompetensi yang harus dimiliki oleh seseorang yang menduduki jabatan pertama, auditor muda, auditor madya, dan auditor utama.

\subsection{Independensi}

\section{a. Pengertian Independensi}

Kata independensi merupakan terjemahan dari kata "independence" 
yang berasal dari Bahasa Inggris. Dalam kamus oxford Advance Learner's Dictionary of Current English terdapat entri kata "independent" bermakna tidak tergantung atau dikendalikan oleh (orang lain atau benda) tidak mendasarkan diri pada orang lain bertindak.

$$
\text { Arens et.al. (2011:74) }
$$

Independensi dalam audit berarti mengambil sudut pandang yang tidak bias dalam melakukan pengujian audit, evaluasi atas hasil pengujian dan penerbitan laporan audit.

Sharaf et.al. dalam Tuankotta (2011:64) menyatakan bahwa independensi mencerminkan sikap tidak memihak serta tidak dibawah pengaruh atau tekanan pihak tertentu dalam mengambil tindakan dan keputusan.

Mulyadi (2010:87) menjelaskan independensi adalah sikap mental yang bebas dari pengaruh, tidak dikendalikan oleh pihak lain, tidak tergantung pada orang lain. Independensi juga berarti adanya kejujuran dalam diri auditor dalam mempertimbangkan fakta dan adanya pertimbangan yang objektif tidak memihak dalam diri auditor dalam memuaskan dan menyatakan pendapatnya.

Independensi merupakan salah satu komponen etika yang harus dijaga atau dipertahankan oleh akuntan publik. Independen berarti akuntan publik tidak mudah dipengaruhi, karena ia melaksanakan pekerjaan untuk kepentingan umum. Auditor berkewajiban untuk jujur tidak hanya kepada manajemen dan pemilik perusahaan, namun juga kepada kreditur dan pihak lain yang meletakan kepercayaan atas pekerjaan akuntan publik.
Christiawan (2002) Sikap mental independen tersebut meliputi independen dalam fakta (in fact) maupun dalam penampilan (in appearance). Independensi bertujuan untuk menambah kredibilitas laporan keuangan yang disajikan oleh manajemen. Jika akuntan tidak independen terhadap kliennya, maka opininya tidak akan memberikan tambahan apapun.

\section{b. Faktor-Faktor yang mempengaruhi Independensi}

Jusuf (2011:75) menyatakan bahwa ada lima yang mempengaruhi independensi, yaitu:

1) Kepemilikan finansial yang Signifikan

Kepemilikan finansial dalam perusahaan yang diaudit termasuk kepemilikan dalam instrumen utang dan modal (misal pinjaman dan obligasi) dan kepemilikan dalam instrumen derivatif (misalnya opsi). Standar etika juga melarang auditor menduduki posisi sebagai penasihat, direksi, maupun memiliki saham yang jumlahnya signifikan di perusahaan klien.

2) Pemberian Jasa Non-Audit

Konflik kepentingan yang paling nyata bagi Kantor Akuntan Publik dalam memberikan jasa non-audit pada kliennya terus menerus menjadi perhatian penting bagi para pembuat regulasi dan pengamat.

3) Imbalan jasa Non-Audit dan Independensi

Cara auditor untuk berkompetensi mendapatkan klien dan menetapkan imbalan jasa audit dapat memberikan implikasi penting bagi kemampuan auditor untuk menjaga independensi auditnya.

4) Tindakan hukum antara KAP dan Klien, serta Independensi 
Ketika terdapat tindakan hukum atau niat untuk memulai tindakan hukum antara sebuah KAP dengan kliennya, maka kemampuan KAP dan kliennya untuk tetap objektif dipertanyakan. Tindakan hukum oleh klien untuk jasa perpajakan atau jasa-jasa non-audit lainnya, atau tindakan melawan klien maupun KAP oleh pihak lain tidak akan menurunkan independensi dalam pekerjaan audit.

5) Pergantian Auditor

Riset dibidang audit mengindikasikan beragam alasan dimana manajemen dapat memutuskan untuk mengganti auditornya. Alasan alasan tersebut termasuk mencari pelayanan dengan kualitas yang lebih baik, opinion shopping, dan mengurangi biaya.

\subsection{Profesionalisme Auditor}

\section{a. Pengertian Profesionalisme} Auditor

Definisi profesionalisme menurut kamus besar Bahasa Indonesia (2005:897) Profesionalisme adalah mutu, kualitas, dan tindak tanduk yang merupakan ciri suatu profesi atau orang yang profesional.

$$
\text { Arens et.al. }
$$

profesionalisme auditor adalah bertanggungjawab untuk bertindak lebih baik dari sekedar memenuhi tanggungjawab diri sendiri maupun ketentuan hukum dan peraturan masyarakat. Akuntan publik sebagai profesional mengakui adanya tanggungjawab kepada masyarakat, klien, serta rekan praktisi, termasuk prilaku yang terhormat, meskipun itu berarti pengorbanan diri.

kode etik Profesi Akuntan Publik dalam Institut Akuntan Publik Indonesia (2008:7) dijelaskan pula tentang Prinsip
Dasar yang menunjukan tanggung jawab profesional auditor sebagai seorang Praktisi (Auditor), diantaranya sebagai berikut:

1) Prinsip Integritas

Praktisi harus tegas dan jujur dalam menjalani hubungan profesional dan hubungan bisnis dalam melaksanakan pekerjaannya. Pelayanan dan kepercayaan publik tidak boleh dikalah oleh keuntungan pribadi. Integritas dapat menerima kesalahan yang tidak disengaja dan perbedaan pendapat yang jujur, tetapi tidak menerima kecurangan atau peniadaan prinsip.

2) Prinsip Objektivitas

Setiap praktisi tidak boleh membiarkan subjektivitas, berbenturan kepentingan, atau pengaruh yang tidak layak (undue influence) dari pihak-pihak lain mempengaruhi pertimbangan bisnisnya.

3) Prinsip Kompetensi serta sikap kecermatan dan kehati-hatian profesional

Praktisi wajib memelihara pengetahuan dan keahlian profesionalnya pada suatu tingkatan yang dipersyaratkan secara berkesinambungan, sehingga klien atau pemberi kerja dapat menerima jasa profesional yang diberikan secara kompeten berdasarkan pertimbangan terkini dalam praktik, perundangundangandan metode pelaksanaan pekerjaan. Setiap praktisi harus bertindak secara profesional dan sesuai dengan standar profesi dan kode etik profesi yang berlaku dalam memberikan jasa profesionalnya.

4) Prinsip Kerahasian

Praktisi wajib menjaga kerahasiaan informasi yang diperoleh sebagai hasil dari hubungan profesional 
dan hubungan bisnisnya, serta tidak boleh mengungkapkan informasi tersebut kepada pihak ketiga tanpa persetujuan klien atau pemberi kerja, kecuali jika terdapat kewajiban untuk mengungkapkan sesuai dengan ketentuan hukum atau peraturan lainnya yang berlaku. Informasi rahasia yang diperoleh dari hubungan profesional dan hubungan bisnis tidak boleh digunakan oleh praktisi untuk keuntungan pribadinya atau pihak ketiga.

\section{5) Prinsip Perilaku Profesional}

Praktisi wajib mematuhi hukum dan peraturan yang berlaku umum dan harus menghindari semua tindakan yang dapat mendiskreditkan profesi. Kewajiban untuk menjauhi tingkah laku yang dapat mendiskreditkan profesi harus dipenuhi oleh anggota sebagai perwujudan tanggung jawabnya kepada penerima jasa, pihak ketiga, anggota yang lain, staf, pemberi kerja dan masyarakat umum.

\section{b. Ciri - ciri Profesionalisme Auditor}

Seseorang yang memiliki profesionalisme senantiasa mendorong dirinya untuk mewujudkan aktivitas kerja yang profesional. Kualitas profesional ditandai dengan ciri-ciri sebagai berikut:

1) Keinginan untuk selalu menampilkan perilaku yang mendekati "piawai ideal". Seseorang yang memiliki profesionalisme tinggi akan selalu berusaha mewujudkan dirinya sesuai dengan piawai yang telah ia tetapkan. Ia akan mengidentifikasi dirinya kepada seseorang yang dipandang memiliki piawai tersebut. Yang dimaksud dengan "piawai ideal" adalah suatu perangkat perilaku yang dipandang paling sempurna dan dijadikan sebagai rujukan.

2) Meningkatkan dan memelihara "imej profesion". Profesionalisme yang tinggi ditunjukan oleh besarnya keinginan untuk selalu meningkatkan dan memelihara imej profesion melalui perwujudan prilaku profesional. Perwujudannya dilakukan melalui berbagai cara misalnya penampilan, cara percakapan, penggunaan bahasa, sikap tubuh badan, sikap hidup harian, hubungan dengan individu lainnya.

3) Keinginan untuk senantiasa mengejar kesempatan pengembangan profesional yang dapat meningkatkan dan memperbaiki kualitas pengetahuan dan keterampilan.

4) Mengejar kualitas dan cita-cita dalam profesi. Profesional ditandai dengan rasa bangga akan profesi yang diembannya. Dalam hal ini akan muncul rasa percaya diri akan profesi tersebut.

Pengertian umum, seseorang dikatakan profesional jika memenuhi tiga kriteria, yaitu mempunyai keahlian untuk melaksanakan tugas sesuai dengan bidangnya, melaksanakan suatu tugas atau profesi dengan menetapkan standard baku di bidang profesi yang bersangkutan dan menjalankan tugas profesinya dengan mematuhi Etika Profesi yang telah ditetapkan.

Jadi profesionalisme auditor merupakan sikap dan prilaku auditor dalam menjalankan profesinya dengan kesungguhan dan tanggung jawab agar mencapai kinerja tugas sebagaimana yang diatur dalam organisasi profesi, meliputi pengabdian pada profesi, kewajiban sosial, kemandirian, 
Invoice: Jurnal Ilmu Akuntansi

p-ISSN: 2714-6359 e-ISSN: 2714-6340

Vol.2 Nomor 2 September 2020

keyakinan profesi dan hubungan dengan rekan seprofesi.

\section{c. Ukuran Profesionalisme Auditor}

Konsep profesionalisme yang dikembangkan oleh hall dalam Susanto et. al. (2009) banyak digunakan oleh para peneliti untuk mengukur profesionalisme dari profesi auditor yang tercermin dari sikap dan prilaku.

Hall dalam susanto et.al. (2009:4) terdapat lima dimensi profesionalisme, yaitu:

1) Pengabdian pada Profesi

$$
\text { Pengabdian pada profesi }
$$

dicerminkan dari dedikasi

profesionalisme dengan menggunakan pengetahuan dan kecakapan yang dimiliki. Keteguhan untuk tetap melaksanakan pekerjaan meskipun imbalan ekstrinsik kurang. Sikap ini adalah ekspresi dari pencurahan diri yang total terhadap pekerjaan. Pekerjaan didefinisikan sebagai tujuan, bukan hanya alat untuk mencapai tujuan. Totalitas ini sudah menjadi komitmen pribadi, sehingga kompensasi utama yang diharapkan dari pekerjaan adalah kepuasan rohani, baru kemudian materi.

2) Kewajiban Sosial

$$
\text { Kewajiban sosial adalah }
$$
pandangan tentang pentingnya peranan profesi dan manfaat yang diperoleh baik masyarakat maupun profesional karena adanya pekerjaan tersebut, auditor harus mempunyai pandangan bahwa dengan yang dilaksanakannya untuk kepentingan publik karena dengan pendapat auditnya terhadap suatu laporan keuangan akan mempengaruhi pengambilan keputusan oleh pemakai laporan audit. Oleh karena itu auditor mempunyai kontribusi yang sangat besar bagi masyarakat serta profesinya. Jadi apabila semakin tinggi kewajiban sosial akan semakin tinggi profesionalisme auditor.

3) Kemandirian

Kemandirian dimaksudkan sebagai suatu pandang seseorang yang profesional harus mampu membuat keputusan sendiri tanpa tekanan dari pihak lain (pemerintah, klien, dan bukan anggota profesi). Seorang auditor dituntut harus mampu mengambil keputusan sendiri tanpa adanya dari pihak lain sesuai dengan pertimbangan pertimbangan yang dibuat berdasarkan kondisi dan keadaan yang dihadapinya. Setiap ada campur tangan dari luar dianggap sebagai hambatan kemandirian secara profesional.

4) Keyakinan terhadap Peraturan Profesi

Keyakinan terhadap profesi adalah suatu keyakinan bahwa yang paling berwenang menilai pekerjaan profesional adalah rekan sesama profesi, bukan orang luar yang tidak mempunyai kompetensi dalam bidang ilmu dan pekerjaan mereka.

5) Hubungan dengan Sesama Profesi

Hubungan dengan sesama profesi adalah menggunakan ikatan profesi sebagai acuan, termasuk didalamnya organisasi formal dan kelompok kolega informal sebagai ide utama dalam pekerjaan. Melalui ikatan profesi ini para profesional membangun kesadaran profesional.

\subsection{Etika Auditor}

Payamta (2002) menyatakan bahwa berdasarkan "Pedoman Etika" IFAC, maka syarat syarat etika suatu organisasi akuntan harus sebaliknya didasarkan prinsip - prinsip dasar yang mengatur tindakan/perilaku seorang akuntan dalam melaksanakan tugas profesionalnya. Prinsip tersebut adalah 
(1) Integritas, (2) obyektivitas, (3) Independen, (4) kepercayaan, (4) standar - standar teknis, (6) kemampuan professional, dan (7) perilaku etika. Etika berkaitan dengan pertanyaan tentang bagaimana orang akan berperilaku terhadap sesamanya (Kell et.al, 2002) dalam Alim et.al. (2007).

Kamus Besar Bahasa Indonesia (1995) etika berarti nilai mengenai benar dan salah yang dianut suatu golongan atau masyarakat. Ludigdo et.al. (2001) mendefinisikan etika sebagai seperangkat aturan atau norma atau pedoman yang mengatur perilaku manusia, baik yang harus dilakukan maupun yang harus ditinggalkan yang dianut oleh sekelompok atau segolongan manusia atau masyarakat atau profesi. Lubis (2009) menyatakan auditor harus mematuhi Kode Etik yang ditetapkan. Pelaksanaan audit harus mengacu kepada Standar Audit dan Kode Etik yang merupakan bagian yang tidak terpisahkan dari standar audit.

Kode etik auditor merupakan aturan perilaku auditor sesuai dengan tuntutan profesi dan organisasi serta standar audit yang merupakan ukuran mutu minimal yang harus dicapai oleh auditor dalam menjalankan tugas auditnya, apabila aturan ini tidak dipenuhi berarti auditor tersebut bekerja di bawah standar dan dapat dianggap melakukan malpraktek (Jaafar, 2008 dalam Sari, 2011). Devis (1984) dalam Anitaria (2011) mengemukakan bahwa ketaatan terhadap kode etik hanya dihasilkan dari program pendidikan terencana yang mengatur diri sendiri untuk meningkatkan pemahaman kode etik.

Penelitian yang dilakukan Ludigno et.al. (2001) dalam Susanto et.al. (2008) bertujuan untuk mengetahui faktor - faktor yang dianggap mempengaruhi sikap dan perilaku etis akuntan serta faktor yang dianggap paling dominan pengaruhnya terhadap sikap dan perilaku tidak etis akuntan. Hasil yang diperoleh dari kuesioner tertutup menunjukkan bahwa terdapat sepuluh faktor yang dianggap oleh sebagian besar akuntan mempengaruhi sikap dan perilaku mereka. Sepuluh faktor tersebut adalah religiusitas, pendidikan, organisasional, emotional quotient, lingkungan keluarga, pengalaman hidup, imbalan yang diterima, hukum, dan posisi atau kedudukan.

\subsection{Kualitas Audit}

\section{a. Pengertian Kualitas Audit}

Pengertian Kualitas Audit Mulyadi (2011:43) yaitu Suatu proses sistematik untuk memperoleh dan mengevaluasi bukti secara obyektif mengenai pernyataan-pernyataan tentang kegiatan dan kejadian ekonomis, dengan tujuan untuk menetapkan tingkat kesesuaian antara pernyataan-pernyataan tersebut dengan kriteria yang telah ditetapkan serta penyampaian hasil-hasil kepada pemakai yang berkepentingan. Arens (2011:47) kualitas audit didefinisikan sebagai Proses untuk memastikan bahwa standar auditingnya berlaku umum diikuti oleh setiap audit, mengikuti prosedur pengendalian kualitas khusus membantu memenuhi standar-standar secara konsisten dalam penugasannya hingga tercapai kualitas hasil yang baik.

AAA Financial Accounting standard committee (2001) dalam Christiawan (2003) menyatakan bahwa kualitas audit ditentukan oleh 2 hal, yaitu kompetensi (keahlian) dan independensi kedua hal tersebut berpengaruh langsung terhadap kualitas dan secara potensial saling mempengaruhi lebih lanjut, persepsi 
pengguna laporan keuangan atas kualitas audit merupakan fungsi dari persepsi mereka atas independensi dan keahlian auditor.

\section{b. Standar Pengendalian Kualitas Audit}

Bagi suatu kantor akuntan publik, pengendalian kualitas terdiri dari metode-metode yang digunakan untuk memastikan bahwa kantor itu memenuhi tanggungjawab profesionalnya kepada klien dan pihak-pihak lain. Arens et.al. (2011:48) menyatakan Pengendalian kualitas audit merupakan proses untuk memastikan bahwa standar auditing yang berlaku umum diikuti oleh setiap audit, KAP mengikuti prosedur pengendalian kualitas khusus yang membantu memenuhi standar-standar itu secara konsisten pada setiap penugasannya.

IAI menjelaskan bahwa pelaksanaan standar auditing akan mempengaruhi kualitas audit, standar auditing meliputi (SPAP, 2009: 150.1) menyatakan:

1) Standar Umum

a) Audit harus dilaksanakan oleh seorang atau lebih yang memiliki keahlian dan pelatihan teknis yang cukup sebagai auditor.

b) Dalam semua hal yang berhubungan dengan independensi dalam sikap mental harus dipertahankan oleh auditor

c) Dalam pelaksanaan audit dan penyusunan laporannya, auditor wajib menggunakan kemahiran profesionalnya dengan cermat dan seksama.

2) Standar Pekerjaan Lapangan

a) Pekerjaan harus direncanakan sebaik-baiknya dan jika digunakan asisten harus disupervisi dengan semestinya.

b) Pemahaman memadai atas pengendalian intern harus diperoleh untuk merencanakan audit dan menentukan sifat, saat dan lingkungan pengujian yang akan dilakukan.

c) Bukti audit kompeten yang cukup harus diperoleh melalui inspeksi, pengamatan, permintaan keterangan, dan konfirmasi sebagai dasar memadai untuk menyatakan pendapat atas keuangan yang diaudit.

3) Standar Pelaporan

a) Laporan audit harus menyatakan apakah laporan keuangan telah disusun sesuai dengan prinsip akuntansi yang berlaku umum di indonesia.

b) Laporan audit harus menunjukan atau menyatakan, jika ada ketidak konsistenan penerapan prinsip akuntansi dalam penyusunan laporan keuangan periode berjalan dibandingkan dengan penerapan prinsip akuntansi tersebut dalam periode sebelumnya.

c) Pengungkapan informatif dalam laporan keuangan harus dipandang memadai, kecuali dinyatakan lain dalam laporan auditor.

d) Laporan auditor harus memuat suatu pernyataan pendapat mengenai laporan keuangan secara keseluruhan atau suatu asersi bahwa pernyataan demikian tidak dapat diberikan. Jika pendapat secara keseluruhan tidak dapat diberikan, maka alasannya harus dinyatakan. Dalam hal nama auditor harus memuat petunjuk yang jelas mengenai sifat pekerjaan audit yang dilaksanakan, jika ada dan tingkat 
tanggungjawab yang dipikul oleh auditor.

Arens (2011) juga mengemukakan terdapat 5 unsur pengendalian kualitas, yaitu:

1) Independensi, integritas dan objektivitas.

2) Manajemen kepegawaian.

3) Penerimaan dan kelanjutan klien serta penugasan.

4) Kinerja penugasan konsultasi.

5) Pemantauan prosedur.

\subsection{Pengembangan Hipotesis}

\section{a. Pengaruh Kompetensi Terhadap} Kualitas Audit

Kompetensi auditor adalah auditor yang dengan pengetahuan, pengalaman, pendidikan dan pelatihan yang memadai dan dapat melakukan audit secara objektif dan cermat. Kualitas audit merupakan segala kemungkinan dimana auditor pada saat mengaudit laporan keuangan klien dapat menemukan pelanggaran yang terjadi dalam sistem akuntansi klien dan melaporkannya dalam laporan keuangan audit, dimana dalam melaksanakan tugasnya tersebי't auditor harus berpedoman pada standaı auditing. Dalam melaksanakan proses audit, auditor membutuhkan pengetahuan, pengalaman, pendidikan dan pelatihan yang baik karena dengan hal itu auditor menjadi lebih mampu memahami kondisi keuangan dan laporan keuangan kliennya dan akan menghasilkan kualitas yang baik.

De Angelo dalam Rita dan Sony (2014) menyatakan bahwa kualitas audit merupakan segala kemungkinan dimana auditor pada saat mengaudit laporan keuangan klien dapat menemukan pelanggaran yang terjadi dalam sistem akuntansi klien dan melaporkan temuannya dalam laporan keuangan auditan. De Angelo juga mengatakan bahwa dalam melaksanakan tugasnya tersebut auditor berpedoman pada standar auditing dan kode etik yang relevan.

Oleh karena itu dapat dipahami bahwa seorang auditor yang kompeten atau yang memiliki pengetahuan, pendidikan, pengalaman dan pelatihan yang memadai akan lebih memahami dan mengetahui berbagai masalah laporan keuangan secara lebih mendalam harus secara terus menerus mengikuti perkembangan yang terjadi dalam bisnis dan profesinya dan harus mempelajari, menerapkan ketentuan-ketentuan baru dalam standar auditing yang ditetapkan oleh organisasi profesi untuk meningkatkan kualitas audit. Jadi, dapat disimpulkan bahwa semakin tinggi kompetensi yang dimiliki auditor maka semakin tinggi pula kualitas audit yang diberikan (Handayani 2013: 42-43).

\section{H1: Kompetensi memiliki pengaruh positif terhadap Kualitas Audit.}

\section{b. Pengaruh Independensi Terhadap Kualitas Audit}

Independensi merupakan sikap yang harus dimiliki oleh auditor untuk tidak memiliki kepentingan pribadi dalam melaksanakan tugasnya karena dengan posisi auditor yang independen banyak menimbulkan dilematis baginya yang dapat melanggar standar profesi sebagai acuan dalam melakukan tugasnya. Profesi auditor yang independen, apabila seorang auditor memiliki cara pandang yang tidak memihak siapapun dalam pelaksanaan pengujian evaluasi hasil pemeriksaan dan penyusunan laporan audit. Hal ini, harus dilakukan oleh auditor dengan 
tujuan agar menambah kredibilitas laporan yang disajikan oleh manajemen, karena bila auditor tidak bersikap independen maka kualitas hasil audit tidak baik, sehingga opini yang dihasilkan auditor tidak dapat memberikan tambahan yang berguna bagi klien (Rana 2011:27-28).

Jusuf et.al. (2011:74) menyatakan Independensi dalam audit berarti mengambil sudut pandang yang tidak bias dalam melakukan pengujian audit, evaluasi atas hasil pengujian dan penerbitan laporan audit. Auditor tidak hanya harus independen dalam fakta, tetapi harus independen dalam penampilan. Independen dalam fakta (independence in fact) ada apabila auditor benar-benar mampu mepertahankan sikap tidak bias sepanjang audit, sedangkan independen dalam penampilan (independence in appearance) adalah hasil dari interpretasi lain atas independensi ini (Arens 2011:74). Penelitian yang dilakukan oleh Yaniartha et.al. (2009) menyatakan bahwa Independensi berpengaruh positif signifikan terhadap Kualitas Audit.

\section{H2: Independensi memiliki pengaruh positif terhadap Kualitas Audit.}

\section{c. Pengaruh Profesionalisme Auditor Terhadap Kualitas Audit}

Profesionalisme juga merupakan syarat utama sebagai auditor. profesionalisme auditor mengacu pada kemampuan dan perilaku profesional. Kemampuan didefinisikan sebagai pengetahuan, pengalaman, kemampuan teknologi, dan memungkinkan perilaku profesional auditor untuk mencakup faktor-faktor tambahan seperti transparansi dan tanggung jawab, hal ini sangat penting untuk memastikan kepercayaan publik (Nugrahini 2015: 3132).

Profesionalisme auditor bertanggungjawab untuk bertindak lebih baik dari sekedar memenuhi tanggungjawab diri sendiri maupun ketentuan hukum dan peraturan masyarakat. Akuntan publik sebagai profesional mengakui adanya tanggungjawab kepada masyarakat, klien, serta rekan praktisi, termasuk prilaku yang terhormat, meskipun itu berarti pengorbanan diri. (Arens et.al. 2011:105) .

Untuk meningkatkan kualitas audit, seorang auditor dituntut agar bertindak profesional dalam melakukan pemeriksaan. Auditor yang profesional akan lebih baik dalam menghasilkan audit yang dibutuhkan dan berdampak pada peningkatan kualitas audit. Adanya peningkatan kualitas audit auditor maka meningkat pula kepercayaan pihak yang membutuhkan jasa profesional. Harapan masyarakat terhadap tuntutan transparansi dan akuntabilitas akan terpenuhi jika auditor dapat menjalankan profesionalisme dengan baik sehingga masyarakat dapat menilai kualitas audit (Gede et. al. 2014).

Nastia et.al. (2013) menyatakan bahwa variabel profesionalisme memiliki pengaruh terhadap kualitas audit eksternal seperti auditor yang terdapat pada kantor akuntan publik (KAP). Sebab dengan profesionalisme yang tinggi kebebasan auditor akan terjamin. untuk menjalankan perannya yang menuntut tanggung jawab yang semakin luas, auditor eksternal harus memiliki wawasan yang luas tentang kompleksitas organisasi modern.

H3: Profesionalisme

Auditor memiliki pengaruh positif 
terhadap Kualitas Audit.

\section{d. Etika Auditor Memoderasi Pengaruh Kompetensi Terhadap kualitas Audit}

Benh et. al. (1997) dalam Alim et.al. (2007) mengembangakan atribut kualitas audit yang salah satu diantaranya adalah standar etika yang tinggi, sedangkan atribut-atribut lainnya terkait dengan kompetensi auditor. Audit yang berkualitas sangat penting untuk menjamin bahwa profesi akuntan memenuhi tanggungjawabnya kepada investor, masyarakat umum dan pemerintah serta pihak-pihak lain yang mengandalkan kredibilitas laporan keuangan yang telah diaudit, dengan menegakkan etika yang tinggi (Widagdo et.al. 2002) dalam Alim e.al. (2007). Berdasarkan teori dan penelitian sebelumnya yang memberikan bukti bahwa kompetensi dan etika auditor dalam melakukan audit mempunyai dampak signifikan terhadap kualitas audit.

\section{H4: Etika auditor memperkuat pengaruh kompetensi terhadap kualitas audit.}

e. Etika auditor memoderasi pengaruh independensi terhadap kualitas audit

Penelitian Price et.al. (1976) dalam Alim et.al. (2007) menemukan bahwa ketika auditor dan manajemen tidak mencapai kata sepakat dalam aspek kinerja, maka kondisi ini dapat mendorong manajemen untuk memaksa auditor melakukan tindakan yang melawan standar, termasuk dalam pemberian opini. Kondisi ini akan sangat menyudutkan auditor sehingga ada kemungkinan bahwa auditor akan melakukan apa yang diinginkan oleh pihak manajemen.
Giroux et.al. (1992) dalam Alim et.al. (2007) mengatakan bahwa pada konflik kekuatan, klien dapat menekan auditor untuk melawan standar profesional dan dalam ukuran yang besaran kondisi keuangan klien yang sehat dapat digunakan sebagai alat untuk menekan auditor dengan cara melakukan pergantian auditor. Hal ini dapat membuat auditor tidak akan dapat bertahan dengan tekanan klien tersebut sehingga menyebabkan indepedensi mereka melemah. Posisi auditor juga sangat dilematis dimana mereka dituntut untuk memenuhi keinginan klien namun disatu sisi tindakan auditor dapat melanggar standar profesi sebagai acuan kerja mereka. Hipotesis dalam penelitan mereka terdapat argumen bahwa kemampuan auditor untuk dapat bertahan di bawah tekanan klien mereka tergantung dari kesepakatan ekonomi, lingkungan tertentu, dan perilaku di dalamnya mencangkup etika profesional. Berdasarkan teori dan penelitian sebelumnya yang memberikan bukti bahwa etika auditor dalam melakukan audit mempunyai dampak signifikan terhadap kualitas audit.

\section{H5: Etika auditor memperkuat pengaruh independensi terhadap kualitas audit.}

\section{f. Etika auditor memoderasi pengaruh Profesionalisme terhadap kualitas audit}

Peraturan Menteri Negara

Pendayagunaan Aparatur Negara (MENPAN) PER/05/M.PAN/03/2008 menyebutkan bahwa kualitas auditor dipengaruhi oleh kepatuhan pada kode etik. Febriansyah, dkk (2014) membuktikan bahwa etika akan mempengaruhi hubungan kecermatan professional dengan kualitas auditor. 
Invoice: Jurnal Ilmu Akuntansi

p-ISSN: 2714-6359 e-ISSN: 2714-6340

Vol.2 Nomor 2 September 2020

Dengan demikian, maka di duga bahwa etika auditor akan memperkuat hubungan antara profesionalisme auditor dan kualitas hasil audit yang dilakukannya.

H6: Etika auditor memperkuat pengaruh profesionalisme terhadap kualitas audit.

\section{METODE PENELITIAN}

\subsection{Metode Analisis Data}

Analisis data dilakukan dengan menggunakan bantuan program computer Statistical Product and Service Solutions (SPSS). Metode analisis yang digunakan dalam penelitian ini adalah:

\section{a. Uji Instrumen Penelitian}

Instrumen penelitian sebelum dipergunakan, lebih dahulu diuji dengan memakai pendekatan Uji Validitas dan Realibilitas. Uji validitas digunakan untuk mengukur sah atau valid dan tidaknya suatu kuesioner. Uji validitas dapat dilakukan menggunakan korelasi bivariate antara masing-masing skor indikator dengan total skor konstruk (Ghozali,2006:50). Metode pearson correlation menyatakan butir pertanyaan/ pertanyaan dikatan valid apabila signifikansi butir pertanyaan/pemyataan (2- tailed $\leq 0,05$ dan atau $\leq 0,01$ ).

Kuesioner dikatakan reliable atau andal jika jawaban seseorang terhadap pertanyaan/pertanyaan adalah konsisten atau stabil dari waktu ke waktu dengan menggunakan alat ukur yang sama. Instrumen yarig dipakai dalam variable tersebut dikatakan andal atau reliable jika memberikan nilai cronbach's alpha $>0,60$ (Nunnally, 1960 dalam Ghozali, 2006.46).

\section{b. Pengujian Asumsi Klasik}

Sebelum dilakukan pengujian hipotesis dengan menggunakan analisis regresi, maka diperlukan pengujian asumsi klasik yang meliputi pengujian:

1) Uji Normalitas

Tujuan uji normalitas adalah ingin mengetahui apakah distribusi sebuah data mendekati atau mengikuti distribusi normal, yaitu distribusi data dengan bentuk lonceng (bell shaped). Data yang baik adalah data yang mempunyai pola seperti distribusi normal.

Pedoman pengambilan keputusan dengan uji KolmogravSmirnov tentang data tersebut mendekati atau merupakan distnbusi normal dapat dilihat dari:

a) Nilai signifikan atau probabilitas $<0.05$, maka distribusi data adalah tidak normal.

b) Nilai signifikan atau probabilitas $>0.05$, maka distribusi data adalah normal.

2) Uji Multikolinearitas

Multikolinearitas adalah situasi adanya korelasi variable- variabel independen antara satu dengan yang lainnya. Dalam hal ini disebut variabelvariabel bebas ini tidak orogonal. Variabel-variabel bebas yang bersifat ortogonal adalah variabel bebas yang memiliki nilai korelasi diantara sesamanya sama dengan nol.

Pengujian dilakukan dengan melihat nilai VIF (Variance Inflation Factor) dari model penelitian, jika nilai VIF lebih besar 0,1 dan lebih kecil dari 10 maka tidak terjadi multikolinieritas (Sekaran, 2003:353).

a) Uji Heteroskedastisitas

Tujuan dari pengujian ini adalah untuk menguji apakah dalam sebuah 
model regresi, terjadi ketidaksamaan varians dari residual dari satu pengamatan ke pengamatan lain. Uji heteroskedastisilas dilakukan dengan menggunakan uji Glejser, yaitu meregresi nilai absolut residual terhadap variabel bebas. Jika variabel independen secara signifikan $<0,05$ maka terjadi indikasi masalah heteroskedastisitas.

\section{c. Uji Hipotesis}

1) Moderate Regression Analysis

Dalam upaya mengolah data serta menarik kesimpulan peneliti menggunakan analisis regresi linear berganda atau MRA (Moderate Regression Analysis) dengan persamaan sebagai berikut:

- $\mathrm{Y}=\alpha+\mathrm{b}_{1} \mathrm{X}_{1}+\mathrm{b}_{2} \mathrm{X}_{2}+\mathrm{b}_{3} \mathrm{X}_{3}+\mathrm{b}_{4} \mathrm{M}+\mathrm{e}$ (Model 1)

- $\mathrm{Y}=\alpha+\mathrm{b}_{1} \mathrm{X}_{1}+\mathrm{b}_{4} \mathrm{M}+\mathrm{b}_{5} \mathrm{X}_{1} \mathrm{M}+\mathrm{e}$ (Model 2)

- $\mathrm{Y}=\alpha+\mathrm{b}_{2} \mathrm{X}_{2}+\mathrm{b}_{4} \mathrm{M}+\mathrm{b}_{5} \mathrm{X}_{2} \mathrm{M}+\mathrm{e}$ (Model 3)

- $\mathrm{Y}=\alpha+\mathrm{b}_{3} \mathrm{X}_{3}+\mathrm{b}_{4} \mathrm{M}+\mathrm{b}_{5} \mathrm{X}_{3} \mathrm{M}+\mathrm{e}$ (Model 4)

Keterangan:

$\mathrm{Y}=$ Kualitas Audit

$\beta_{0}=$ Nilai Konstan

$\mathrm{M}=$ Etika Auditor

$\mathrm{X}_{1}=$ Kompetensi

$\mathrm{X}_{2}=$ Independensi

$\mathrm{X}_{3}=$ Profesionalisme

$\mathrm{X}_{1}=$ Interaksi antara kompetensi dan

M etika auditor

$\mathrm{X}_{2}=$ Interaksi antara independensi

M dan etika

$\mathrm{X}_{3}=$ Interaksi antara profesionalisme

M dan etika

$\beta_{1}-=$ Koefisien Korelasi

$\beta_{5}$

$\mathrm{E}=$ Standar error

Moderated Regression Analysis (MRA) menggunakan pendekatan analititik yang mempertahankan integritas sampel dan memberikan dasar untuk mengontrol pengaruh variabel moderator (Ghozali, 2011). Klasifikasi moderasi dapat dilihat pada tabel berikut ini:

Tabel 4.4

Klasifikasi Moderasi

\begin{tabular}{|l|l|}
\hline \multicolumn{1}{|c|}{ Tipe Moderasi } & \multicolumn{1}{c|}{ Koefisien } \\
\hline Pure Moderasi & $\begin{array}{l}\text { B4 tidak } \\
\text { signifikan }\end{array}$ \\
\cline { 2 - 2 } & B5 signifikan \\
\hline Quasi Moderasi & B4 signifikan \\
\cline { 2 - 2 } Homologiser & B5 signifikan \\
\hline Moderasi & $\begin{array}{l}\text { B4 tidak } \\
\text { signifikan }\end{array}$ \\
\cline { 2 - 2 } Prediktor Moderasi & $\begin{array}{l}\text { B5 tidak } \\
\text { signifikan }\end{array}$ \\
\cline { 2 - 2 } & $\begin{array}{l}\text { B4 signifikan } \\
\text { B5 tidak } \\
\text { signifikan }\end{array}$ \\
\hline
\end{tabular}

Pengujian terhadap efek moderasi dapat dilakukan dengan cara sebagai melihat dari signifikansi koefisien $\beta 5$ dari interaksi variabel independen dan variabel moderasi (variabel independen*variabel moderasi) (Jogiyanto, 2010).

2) Uji F (Uji Serempak)

Uji F digunakan untuk mengetahui apakah variabel independen (X1, X2, Xn) secara bersama-sama berpengaruh secara signifikan terhadap variabel dependen (Y). Atau untuk mengetahui apakah model ragresi dapat digunakan untuk memprediksi variabel dependen atau tidak Jika nilai $\mathrm{F}$ dihitung $>\mathrm{F}$ tabel maka model signifikan sebaliknya nilai $\mathrm{F}$ hitung < F tabel maka model tidak signifikan.

3) Uji t (Uji Parsial)

Uji t digunakan untuk mengetahui apakah dalam model regresi variabel independen (X1, X2, ...Xn) secara parsial berpengaruh signifikan terhadap 
variabel dependen (Y). Jika nilai t-hilung $>$ t-tabel, atau level signifikansi $<0.05$ maka model adalah signifikan. Sebaliknya, jika nilai t-hilung $<\mathrm{t}$-tabel, atau level signifikansi $>0.05$ maka model tidak signifikan.

4) Uji Koefisien Determinasi (Adjusted R2)

Analisis ini digunakan untuk mengetahui hubungan antara dua variabel atau lebih variabel independen terhadap variabel dependen serentak. Koefisien ini menunjukkan seberapa besar hubungan yang terjadi antara variabel independen serentak terhadap variabel dependen. Nilai $\mathrm{R}$ berkisar antara 0 sampai 1 , nilai semakin mendekati 1 berarti hubungan yang terjadi semakin kuat, sebaliknya nilai semakin mendekati 0 maka hubungan yang terjafi semakin lemah.

\subsection{Defenisi Operasional Dan Pengukurannya}

\section{a. Variabel Bebas (Independent Variable)}

Sugiyono (2013:59) variabel bebas (independent variable) adalah variabel yang mempengaruhi atau yang menjadi sebab perubahannya atau timbulnya variabel terikat (dependent variable). Dalam penelitian ini yang menjadi variabel bebas (independent variable) adalah Kompetensi, Independensi, dan profesionalisme auditor.

Berikut penjelasan singkat mengenai variabel bebas tersebut:

1) Kompetensi

Kompetensi adalah Suatu kecakapan dan kemampuan dalam menjalankan suatu pekerjaan atau profesinya. Orang yang kompeten berarti orang yang dapat menjalankan pekerjaannya dengan kualitas hasil yang baik. Dalam arti luas kompetensi mencakup

penguasaan

ilmu/pengetahuan (knowledge), dan keterampilan (skill) yang mencukupi, serta mempunyai sikap dan perilaku (attitude) yang sesuai untuk melaksanakan pekerjaan atau profesinya (Sukrisno Agoes 2013:146).

2) Independensi

Penelitian ini mengambil konsep Arens (2011:74) menyatakan Independensi dalam audit berarti mengambil sudut pandang yang tidak bias dalam melakukan pengujian audit, evaluasi atas hasil pengujian dan penerbitan laporan audit.

3) Profesionalisme Auditor

Arens (2011:105) menyatakan Profesionalisme auditor adalah bertanggungjawab untuk bertindak lebih baik dari sekedar memenuhi tanggungjawab diri sendiri maupun ketentuan hukum dan peraturan masyarakat. Akuntan publik sebagai profesional mengakui adanya tanggungjawab kepada masyarakat, klien, serta rekan praktisi, termasuk prilaku yang terhormat, meskipun itu berarti pengorbanan diri).

4) Etika Auditor

Kell et.al. (2002) dalam Alim et.al. (2007) menyatakan etika berkaitan dengan pertanyaan tentang bagaimana orang akan berperilaku terhadap sesamanya. Ludigdo et.al. (2001) mendefinisikan etika sebagai seperangkat aturan atau norma atau pedoman yang mengatur perilaku manusia, baik yang harus dilakukan maupun yang harus ditinggalkan yang dianut oleh sekelompok atausegolongan manusia atau masyarakat atau profesi.

5) Variabel Terikat (Depedent Variable)

Sugiyono (2013:59), variabel terikat (dependent variable) adalah Variabel terikat (dependent variable) 
Invoice: Jurnal Ilmu Akuntansi

p-ISSN: 2714-6359 e-ISSN: 2714-6340

Vol.2 Nomor 2 September 2020

merupakan variabel yang dipengaruhi atau yang menjadi akibat karena adanya variabel bebas. Sesuai dengan masalah yang akan diteliti maka yang akan menjadi variabel terikat (dependent variable) adalah Kualitas Audit.

Arens (2011:47) kualitas audit di definisikan sebagai proses untuk memastikan bahwa standar auditingnya berlaku umum diikuti oleh setiap audit, mengikuti prosedur pengendalian kualitas khusus membantu memenuhi standar-standar secara konsisten dalam penugasannya hingga tercapai kualitas audit yang baik.

4. HASIL DAN PEMBAHASAN

4.1 Hasil Penelitian

a. Deskripsi Jawaban Responden Terhadap variabel Kompetensi

Tabel 5.5

Distribusi Jawaban Responden Variabel Kompetensi

\begin{tabular}{|c|c|c|c|c|c|c|c|c|c|c|c|c|}
\hline \multirow[t]{3}{*}{ X1 } & \multicolumn{10}{|c|}{ Kompetensi } & \multirow{3}{*}{ Skor } & \multirow{3}{*}{ Rerata } \\
\hline & \multicolumn{2}{|c|}{ STS } & \multicolumn{2}{|c|}{ TS } & \multicolumn{2}{|c|}{ KS } & \multicolumn{2}{|c|}{$\mathbf{S}$} & \multicolumn{2}{|c|}{ SS } & & \\
\hline & $\mathbf{F}$ & $\%$ & $\mathbf{F}$ & $\%$ & $\mathbf{F}$ & $\%$ & $\mathbf{F}$ & $\%$ & $\mathbf{F}$ & $\%$ & & \\
\hline 1 & 1 & 1,3 & 8 & 10,7 & 31 & 42,3 & 30 & 40,0 & 5 & 6,7 & 255 & 3,40 \\
\hline 2 & 3 & 4,0 & 12 & 16,0 & 22 & 29,3 & 36 & 48,0 & 2 & 2,7 & 247 & 3,29 \\
\hline 3 & 4 & 5,3 & 16 & 21,3 & 24 & 32,0 & 25 & 33,3 & 6 & 8,0 & 238 & 3,17 \\
\hline 4 & 1 & 1,3 & 12 & 16,0 & 28 & 37,3 & 30 & 40,0 & 4 & 5,3 & 249 & 3,32 \\
\hline
\end{tabular}

Sumber: Output SPSS, 2020

Berdasarkan tabel di atas, diketahui bahwa dari tiga dimensi variable kompetensi, dimensi yang paling dominan adalah dimensi Kognitif, khususnya pada indikator "Pendidikan formal" dengan nilai rata - rata 3,40.
Sementara itu, dimensi yang paling rendah adalah dimensi Afeksi indikator "integritas" dengan nilai rata - rata 3,17.

b. Deskripsi Jawaban Responden Terhadap variable Independensi

Tabel 5.6

Distribusi Jawaban Responden Variabel Independensi

\begin{tabular}{|c|c|c|c|c|c|c|c|c|c|c|c|c|}
\hline \multirow[t]{3}{*}{$\mathrm{X} 2$} & \multicolumn{10}{|c|}{ Independensi } & \multirow{3}{*}{ Skor } & \multirow{3}{*}{ Rerata } \\
\hline & \multicolumn{2}{|c|}{ STS } & \multicolumn{2}{|c|}{ TS } & \multicolumn{2}{|c|}{ KS } & \multicolumn{2}{|c|}{$S$} & \multicolumn{2}{|c|}{ SS } & & \\
\hline & $\mathbf{F}$ & $\%$ & $\mathbf{F}$ & $\%$ & $\mathbf{F}$ & $\%$ & $F$ & $\%$ & $\mathbf{F}$ & $\%$ & & \\
\hline 1 & 0 & 0,0 & 10 & 13,3 & 29 & 38,7 & 30 & 40,0 & 6 & 8,0 & 257 & 3,43 \\
\hline 2 & 0 & 0,0 & 10 & 13,3 & 36 & 48,0 & 22 & 29,3 & 7 & 9,3 & 251 & 3,35 \\
\hline 3 & 0 & 0,0 & 11 & 14,7 & 27 & 36,0 & 36 & 48,0 & 1 & 1,3 & 252 & 3,36 \\
\hline 4 & 0 & 0,0 & 12 & 16,0 & 30 & 40,0 & 26 & 34,7 & 7 & 9,3 & 253 & 3,37 \\
\hline
\end{tabular}

Sumber: Output SPSS, 2020

Berdasarkan tabel di atas, diketahui bahwa dari tiga dimensi variable independensi, dimensi yang paling dominan adalah dimensi Programing Independence, khususnya pada indikator "bebas dari tekanan atau intervensi manajerial" dengan nilai rata rata 3,43 . Sementara itu, dimensi yang paling rendah adalah dimensi Programing Independence indikator "bebas dari intervensi apapun atau dari sikap tidak koperatif" dengan nilai rata rata 3,35 .

c. Deskripsi Jawaban Responden Terhadap variable Profesionalisme 
Tabel 5.7

Distribusi Jawaban Responden Variabel Profesionalisme

\begin{tabular}{|c|c|c|c|c|c|c|c|c|c|c|c|c|}
\hline \multirow[t]{3}{*}{$\mathrm{X3}$} & \multicolumn{10}{|c|}{ Profesionalisme } & \multirow[t]{3}{*}{ Skor } & \multirow[t]{3}{*}{ Rerata } \\
\hline & \multicolumn{2}{|c|}{ STS } & \multicolumn{2}{|c|}{ TS } & \multicolumn{2}{|c|}{ KS } & \multicolumn{2}{|c|}{$S$} & \multicolumn{2}{|c|}{ SS } & & \\
\hline & $\mathbf{F}$ & $\%$ & $\mathbf{F}$ & $\%$ & $\mathbf{F}$ & $\%$ & $\mathbf{F}$ & $\%$ & $\mathbf{F}$ & $\%$ & & \\
\hline 1 & 1 & 1,3 & 13 & 17,3 & 34 & 45,3 & 24 & 32,0 & 3 & 4,0 & 240 & 3,20 \\
\hline 2 & 3 & 4,0 & 18 & 24,0 & 30 & 40,0 & 15 & 20,0 & 9 & 12,0 & 234 & 3,12 \\
\hline 3 & 5 & 6,7 & 17 & 22,7 & 29 & 38,7 & 21 & 28,0 & 3 & 4,0 & 225 & 3,00 \\
\hline 4 & 2 & 2,7 & 19 & 25,3 & 30 & 40,0 & 22 & 29,3 & 2 & 2,7 & 228 & 3,04 \\
\hline 5 & 2 & 2,7 & 17 & 22,7 & 23 & 30,7 & 31 & 41,3 & 2 & 2,7 & 239 & 3,19 \\
\hline
\end{tabular}

Sumber: Output SPSS, 2020

Berdasarkan tabel di atas, diketahui bahwa dari lima dimensi variable profesionalisme, dimensi yang paling dominan adalah dimensi Pengabdian pada Profesi, pada indikator "auditor menggunakan segenap pengetahuan dalam proses audit" dengan nilai rata - rata 3,20. Sementara itu, dimensi yang paling rendah adalah dimensi Kemandirian indikator "yakin terhadap keputusan yang diambil" dengan nilai rata - rata 3,00.

\section{d. Deskripsi Jawaban RespondenTerhadap variable Etika Auditor}

Tabel 5.8

Distribusi Jawaban Responden Variabel Etika Auditor

\begin{tabular}{|c|c|c|c|c|c|c|c|c|c|c|c|c|}
\hline \multirow[t]{3}{*}{$\mathbf{M}$} & \multicolumn{10}{|c|}{ Etika Auditor } & \multirow{3}{*}{ Skor } & \multirow{3}{*}{ Rerata } \\
\hline & \multicolumn{2}{|c|}{ STS } & \multicolumn{2}{|c|}{ TS } & \multicolumn{2}{|c|}{ KS } & \multicolumn{2}{|c|}{$S$} & \multicolumn{2}{|c|}{ SS } & & \\
\hline & $\mathbf{F}$ & $\%$ & $F$ & $\%$ & F & $\%$ & $\mathbf{F}$ & $\%$ & $F$ & $\%$ & & \\
\hline 1 & 3 & 4,0 & 14 & 18,7 & 28 & 37,3 & 25 & 33,3 & 5 & 6,7 & 240 & 3,20 \\
\hline 2 & 1 & 1,3 & 12 & 16,0 & 23 & 30,7 & 31 & 41,3 & 8 & 10,7 & 258 & 3,44 \\
\hline 3 & 2 & 2,7 & 15 & 20,0 & 27 & 36,0 & 26 & 34,7 & 5 & 6,7 & 242 & 3,23 \\
\hline 4 & 1 & 1,3 & 9 & 12,0 & 31 & 41,3 & 27 & 36,0 & 7 & 9,3 & 255 & 3,40 \\
\hline
\end{tabular}

Sumber: Output SPSS, 2020

Berdasarkan tabel di atas, diketahui bahwa dari empat indikator variable etika auditor, indikator yang paling dominan adalah indikator "organisasi auditor" dengan nilai rata rata 3,44. Sementara itu, indikator yang paling rendah adalah indikator "imbalan yang diterima auditor" dengan nilai rata - rata 3,20

e. Deskripsi Jawaban Responden Terhadap variable Kualitas Audit

Tabel 5.9

Distribusi Jawaban Responden Variabel Kualitas Audit

\begin{tabular}{|c|c|c|c|c|c|c|c|c|c|c|c|c|}
\hline \multirow[t]{3}{*}{$\mathbf{Y}$} & \multicolumn{10}{|c|}{ Kualitas Audit } & \multirow{3}{*}{ Skor } & \multirow{3}{*}{ Rerata } \\
\hline & \multicolumn{2}{|c|}{ STS } & \multicolumn{2}{|c|}{ TS } & \multicolumn{2}{|c|}{ KS } & \multicolumn{2}{|c|}{$\mathbf{S}$} & \multicolumn{2}{|c|}{ SS } & & \\
\hline & $\mathbf{F}$ & $\%$ & $\mathbf{F}$ & $\%$ & $\mathbf{F}$ & $\%$ & $\mathbf{F}$ & $\%$ & $F$ & $\%$ & & \\
\hline 1 & 0 & 0,0 & 11 & 14,7 & 29 & 38,7 & 32 & 42,7 & 3 & 4,0 & 252 & 3,36 \\
\hline
\end{tabular}


Invoice: Jurnal Ilmu Akuntansi

p-ISSN: 2714-6359 e-ISSN: 2714-6340

Vol.2 Nomor 2 September 2020

\begin{tabular}{|l|l|l|l|l|l|l|l|l|l|l|l|l|}
\hline \hline 2 & 0 & 0,0 & 15 & 20,0 & 34 & 45,3 & 24 & 32,0 & 2 & 2,7 & 238 & 3,17 \\
\hline 3 & 0 & 0,0 & 13 & 17,3 & 36 & 48,0 & 23 & 30,7 & 3 & 4,0 & 241 & 3,21 \\
\hline 4 & 0 & 0,0 & 10 & 13,3 & 27 & 36,0 & 32 & 42,7 & 6 & 8,0 & 259 & 3,45 \\
\hline
\end{tabular}

Sumber: Output SPSS, 2020

Berdasarkan tabel di atas, diketahui bahwa dari dua dimensi variable kualitas audit, dimensi yang paling dominan adalah dimensi Outcome Orientes, pada indikator "spesialisasi auditor" dengan nilai rata - rata 3,45. Sementara itu, dimensi yang paling rendah adalah dimensi Process Oriented indikator "pengujian dan pengendalian substantive transaksi" dengan nilai rata rata 3,17 .

\section{f. Uji Validitas dan Uji Reliabitas}

1) Uji Validitas
Pengujian validitas menunjukkan ketelitian serta ketepatan kuesioner yang dibagikan kepada responden. Untuk mengetahui validitas pertanyaan dari setiap variabel, maka rhitung dibandingkan dengan r-tabel. r-tabel dapat dihitung dengan $\mathrm{df}=\mathrm{N}-2$. Jumlah responden dalam penelitian ini sebanyak 75 , sehingga $d f=75-2=73$, $r(?: 73)=$ 0,191. Jika r-hitung> r-tabel, maka pertanyaan tersebut dikatakan valid.

Tabel 5.10

Uji Validitas

\begin{tabular}{|c|c|c|c|}
\hline Variabel & Item & $\mathbf{r}_{\text {hitung }}>\mathbf{r}_{\text {tabel }}$ & Keterangan \\
\hline \multirow[t]{4}{*}{ Kompetensi (X1) } & 1 & $0,811>0,191$ & Valid \\
\hline & 2 & $0,847>0,191$ & Valid \\
\hline & 3 & $0,847>0,191$ & Valid \\
\hline & 4 & $0,810>0,191$ & Valid \\
\hline \multirow[t]{4}{*}{ Independensi (X2) } & 1 & $0,799>0,191$ & Valid \\
\hline & 2 & $0,842>0,191$ & Valid \\
\hline & 3 & $0,805>0,191$ & Valid \\
\hline & 4 & $0,836>0,191$ & Valid \\
\hline \multirow[t]{5}{*}{ Profesionalisme (X3) } & 1 & $0,752>0,191$ & Valid \\
\hline & 2 & $0,748>0,191$ & Valid \\
\hline & 3 & $0,780>0,191$ & Valid \\
\hline & 4 & $0,896>0,191$ & Valid \\
\hline & 5 & $0,802>0,191$ & Valid \\
\hline \multirow[t]{4}{*}{ Etika Auditor (M) } & 1 & $0,880>0,191$ & Valid \\
\hline & 2 & $0,811>0,191$ & Valid \\
\hline & 3 & $0,888>0,191$ & Valid \\
\hline & 4 & $0,754>0,191$ & Valid \\
\hline \multirow[t]{4}{*}{ Kualitas Audit (Y) } & 1 & $0,877>0,191$ & Valid \\
\hline & 2 & $0,793>0,191$ & Valid \\
\hline & 3 & $0,750>0,191$ & Valid \\
\hline & 4 & $0,833>0,191$ & Valid \\
\hline
\end{tabular}


Sumber: Data primer diolah, 2020

Hasil uji validitas menunjukkan bahwa semua item pertanyaan dalam dalam kuesioner adalah valid dan dapat digunakan sebagai alat ukur penelitian. Hal ini dibuktikan dengan nilai Corrected Item - Total > 0,191.

\section{2) Uji Reliabilitas}

Pengujian

reliabilitas

menunjukkan seberapa besar suatu instrument tersebut dapat dipercaya dan digunakan sebagai alat pengumpul data. Reliabilitas instrumen yang semakin tinggi, menunjukkan hasil ukur yang didapatkan semakin terpercaya (reliabel). Penentuan reabilitas instrumen suatu penelitian adalah:

a) Jika cronbach's alpha < 0,6 maka reabiliti dikatakan buruk;

b) Jika cronbach's alpha 0,6 - 0,8 maka reabiliti dikatakan cukup; dan

c) Jika cronbach's alpha $>0,8$ maka reabiliti dikatakan baik.

Berikut adalah hasil uji reliabilitas atas variable - variabel:

Tabel 5.11

Uji Reliabilitas

\begin{tabular}{|l|c|c|}
\hline \multicolumn{1}{|c|}{ Variabel } & $\begin{array}{c}\text { Koefisie } \\
\text { n Alpha }\end{array}$ & $\begin{array}{c}\text { Ketera } \\
\text { ngan }\end{array}$ \\
\hline Kompetensi (X1) & 0,846 & Baik \\
\hline $\begin{array}{l}\text { Independensi } \\
\text { (X2) }\end{array}$ & 0,837 & Baik \\
\hline $\begin{array}{l}\text { Profesionalisme } \\
\text { (X3) }\end{array}$ & 0,851 & Baik \\
\hline Etika Auditor (M) & 0,855 & Baik \\
\hline Kualitas Audit (Y) & 0,829 & Baik \\
\hline
\end{tabular}

Sumber: Data primer diolah, 2020

Berdasarkan hasil pengujian reliabilitas, menunjukkan bahwa semua variabel yang dijadikan instrumen dalam penelitian adalah reliabel dan dapat digunakan sebagai alat pengumpulan data. Sehingga berdasarkan hasil uji reliabil itas diatas, menunjukkan bahwa instrument memiliki tingkat reliabilitas yang tinggi, hal ini dibuktikan dengan nilai koefisien alpha>0,60, jadi hasil ukur yang akan didapatkan dapat dipercaya.

\section{g. Uji Asumsi Klasik} 1) Uji Normalitas

Uji normalitas dilakukan untuk melihat apakah dalam model regresi variabel terikat dan variabel bebas keduanya mempunyai distribusi normal atau tidak. Model regresi yang baik adalah model regresi yang berdistribusi normal. Cara mendeteksi normalitas dilakukan dengan melihat grafik histogram.

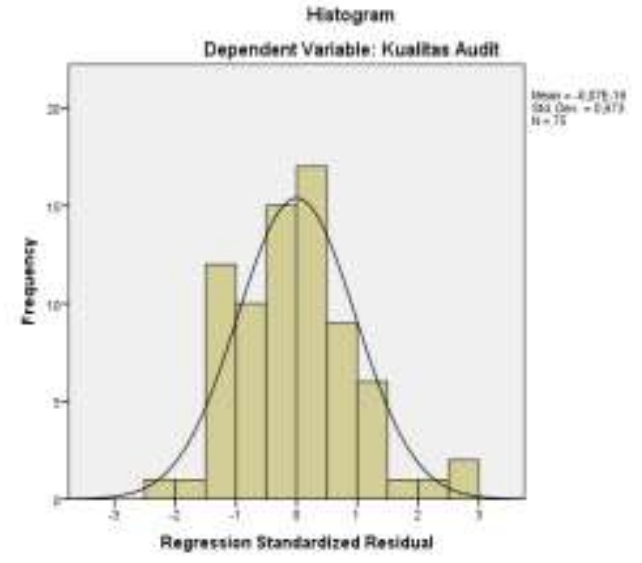

Gambar 5.1

\section{Grafik Histogram}

Sumber: Output SPSS, 2020

Berdasarkan grafik histogram diatas, dapat disimpulkan bahwa grafik histogram memberikan pola distribusi yang mendekati normal, hal ini dibuktikan dengan melihat bahwa grafik membentuk simetris dan mengikuti garis diagonal. Akan tetapi grafik histogram ini hasilnya tidak terlalu akurat apalagi ketika jumlah sampel yang digunakan kecil.

Metode yang handal adalah dengan melihat normal probability plot. Pada grafik normal plot terlihat titik-titik 
menyebar disekitar garis diagonal serta penyebarannya mengikuti arah garis diagonal.

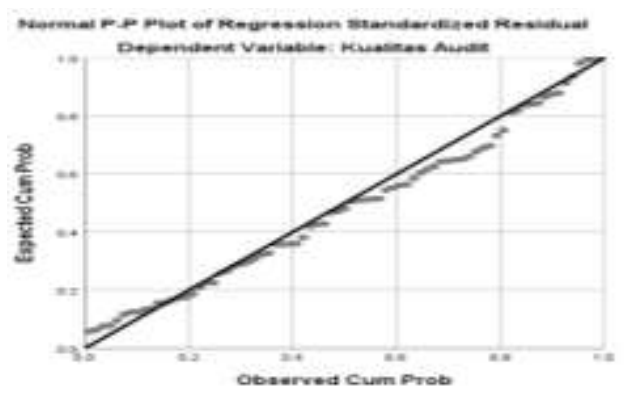

Gambar 5.2

Normal Prabability Plot

Sumber: Output SPSS, 2020

Berdasarkan grafik normal probability plot, dapat dilihat bahwa titik menyebar disekitar garis diagonal dan penyebarannya mengikuti garis diagonal, sehingga dapat dikatakan bahwa pola distribusinya normal. Melihat kedua grafik diatas, dapat disimpulkan bahwa model regresi dalam penelitian ini dapat digunakan karena memenuhi asumsi normalitas.

\section{2) Uji Heteroskedastisitas}

Heteroskedastisitas menunjukkan bahwa variansi variabel tidak sama untuk semua pengamatan. Jika variansi dari residual satu pengamatan ke pengamatan yang lain tetap, maka disebut homoskedastisitas. Model regresi yang baik adalah yang homoskedastisitas atau tidak terjadi heteroskedastisitas karena data cross section memiliki data yang mewakili berbagai ukuran (kecil, sedang, dan besar). Untuk mendeteksi adanya Heteroskedastisitas, metode yang digunakan adalah metode chart (diagram Scatterplot). Jika:

a) Jika ada pola tertentu terdaftar titiktitik, yang ada membentuk suatu pola tertentu yang beraturan (bergelombang, melebar, kemudian menyempit), maka terjadi

Heteroskedastisitas.

b) Jika ada pola yang jelas, serta titiktitik menyebar keatas dan dibawah 0 pada sumbu Y, maka tidak terjadi Heteroskedastisitas.

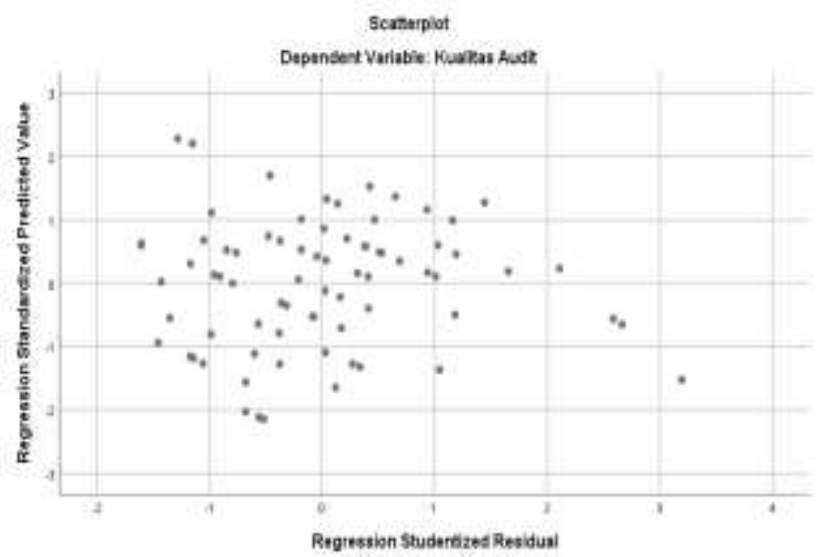

Gambar 5.3 Diagram Scatterplot

Sumber: Output SPSS, 2020

Berdasarkan diagram diatas, maka dapat dilihat bahwa data tersebar secara acak dan tidak membentuk suatu pola tertentu, hal ini menunjukkan bahwa tidak terdapat heteroskedastisitas. Dengan demikian dapat disimpulkan bahwa terjadinya perbedaan varians dari residual dari suatu pengamatan ke pengamatan yang lain.

\section{3) Uji Multikolienaritas}

Uji Multikolinearitas bertujuan menguji adanya korelasi antara variabel bebas (independent) pada model regresi. Pada model regresi yang baik seharusnya tidak terjadi korelasi diantara variabel. Untuk menguji ada atau tidaknya multikolinearitas dalam model regresi dapat dilihat dari nilai tolerance dan lawannya, yaitu dengan melihat variance inflation factor (VIF). Nilai cut-off yang umum dipakai adalah nilai tolerance 0,01 . Salah satu cara untuk menguji adanya multikoloniearitas dapat dilihat dari Variance Inflation Factor (VIF). Jika 
Invoice: Jurnal Ilmu Akuntansi

p-ISSN: 2714-6359 e-ISSN: 2714-6340

Vol.2 Nomor 2 September 2020

nilai $\quad$ VIF $>10$ maka terjadi multikolinearitas.

Tabel 5.12

Uji Multikolinearitas

\begin{tabular}{|l|c|c|}
\hline \multicolumn{1}{|c|}{ Variabel } & VIF & Keterangan \\
\hline Kompetensi (X1) & 1,550 & Tidak Multikolinearitas \\
\hline Independensi (X2) & 2,366 & Tidak Multikolinearitas \\
\hline Profesionalisme (X3) & 2,993 & Tidak Multikolinearitas \\
\hline Etika Auditor (M) & 1,421 & Tidak Multikolinearitas \\
\hline
\end{tabular}

Sumber: Output SPSS, 2020

Berdasarkan tabel di atass, dapat disimpulkan bahwa model regresi untuk variabel independen yang diajukan oleh peneliti untuk diteliti bebas dari multikolinearitas. Hal ini dapat dibuktikan dengan melihat table diatas yang menunjukkan nilai VIF dari masingmasing variabel independen $<10$, dan dapat digunakan untuk mengetahui pengaruh pengintegrasian terhadap kualitas audit.

\section{h. Hasil Uji Model 1}

Pengujian model 1 dilakukan untuk mengetahui pengaruh kompetensi, independensi dan profesionalisme terhadap kualitas audit. Berikut akan diuraikan hasil pengujian model 1 dalam penelitian ini.

\section{1) Uji Koefisien Determinasi Model 1}

Koefisien determinasi digunakan untuk menguji persentase pengaruh variabel independen terhadap variabel dependen. Nilai $R$ Square yang mendekati angka 1 menunjukan bahwa pengaruh variabel independen terhadap variabel dependen semakin besar (Ghozali, 2011). Hasil uji koefisien determinasi dapat dilihat pada tabel berikut:

Tabel 5.13

Hasil Uji Koefisien Determinasi Model 1

\begin{tabular}{ll|r|r|r|r} 
Model & $\mathrm{R}$ & \multicolumn{1}{|c|}{ R Square } & $\begin{array}{c}\text { Adjusted R } \\
\text { Square }\end{array}$ & $\begin{array}{c}\text { Std. Error of the } \\
\text { Estimate }\end{array}$ & Durbin-Watson \\
\hline 1 &, $794^{\mathrm{a}}$ & $\mathbf{, 6 3 1}$ &, 610 &, 40811 & 1,873 \\
\hline
\end{tabular}

Sumber: Output SPSS, 2020

Berdasarkan tabel di atas, menunjukkan bahwa nilai koefisien determinasi (R-Square) sebesar 0,631 atau $63,1 \%$. Artinya variabel kualitas audit mampu dijelaskan oleh variabel kompetensi, independensi, profesionalisme dan etika auditor sebesar $63,1 \%$ dan sisanya yaitu $36,9 \%$, dijelaskan oleh variabel-variabel lain diluar variabel pada model penelitian.

\section{2) Uji t Model 1}

Uji $\mathrm{t}$ digunakan untuk menguji pengaruh variabel independen dengan variabel dependen secara individu. Jika nilai probabilitasnya $<0,05$ maka menunjukan bahwa variabel independen berpengaruh terhadap variabel dependen (Ghozali, 2011). Uji t pada penelitian ini adalah sebagai berikut:

Tabel 5.14

Hasil Uji t Model 1 


\begin{tabular}{|c|c|c|c|c|c|c|}
\hline \multirow{2}{*}{\multicolumn{2}{|c|}{ Model }} & \multicolumn{2}{|c|}{$\begin{array}{c}\text { Unstandardized } \\
\text { Coefficients }\end{array}$} & \multirow{2}{*}{$\begin{array}{c}\text { Standardized } \\
\text { Coefficients } \\
\text { Beta } \\
\end{array}$} & \multirow[b]{2}{*}{$\mathrm{T}$} & \multirow[b]{2}{*}{ Sig. } \\
\hline & & B & Std. Error & & & \\
\hline \multirow[t]{5}{*}{1} & (Constant) & 204 & ,337 & & 606, & ,546 \\
\hline & Kompetensi & ,412 & ,090 & , 474 & 4,564 & ,000 \\
\hline & Independensi & .218 & .106 & .243 & 2.057 & .035 \\
\hline & Profesionalisme & ,256 & ,083 & ,269 & 3,091 & ,003 \\
\hline & Etika Audit & ,184 & 091 & , 185 & 2,022 & ,047 \\
\hline
\end{tabular}

Sumber: Output SPSS, 2019

Berdasarkan tabel di atas diketahui persamaan regresi linear sebagai berikut:

\section{$\mathrm{Y}=0,204+0,412 \mathrm{X} 1+0,218 \mathrm{X} 2+$ $0,256 \times 3+0,184 M$}

Berdasarkan persamaan di atas dapat diuraikan beberapa hal sebagai berikut:

a. Konstanta sebesar 0,204. Hal ini berarti jika tidak ada perubahan pada variable kompetensi, independensi, profesionalisme dan etika auditor maka nilai kualitas audit sebesar 0,204 .

b. Koefisien variabel kompetensi sebesar 0,412. Hal ini berarti bahwa kompetensi berpengaruh positif terhadap kualitas audit. Jika terjadi peningkatan kompetensi sebesar satu satuan maka kualitas audit akan meningkat sebesar 0,412 .

c. Koefisien variable independensi sebesar 0,218. Hal ini berarti bahwa independensi berpengaruh positif terhadap kualitas audit. Jika terjadi peningkatan independensi sebesar satu satuan maka kualitas audit akan meningkat sebesar 0,218.

d. Koefisien variable profesionalisme sebesar 0,256. Hal ini berarti bahwa profesionalisme berpengaruh positif terhadap kualitas audit. Jika terjadi peningkatan profesionalisme sebesar satu satuan maka kualitas audit akan meningkat sebesar 0,256. e. Berdasarkan tabel di atas juga diketahui nilai signifikansi setiap variabel. Berikut akan diuraikan uji signifikansi setiap variabel dalam penelitian ini.

\section{3) Pengaruh kompetensi terhadap kualitas audit.}

Berdasarkan tabel uji $\mathrm{t}$ di atas diketahui bahwa nilai Sig variabel kompetensi aedalah sebesar 0,000, dan nilai tersebut lebih kecil dari derajat kesalahan $(\alpha=0,05)(0,000<0,05)$. Hal ini berarti kompetensi berpengaruh signifikan terhadap kualitas audit. Dengan demikian maka hipotesis pertama (H1) yang di ajukan dalam penelitian ini di mana, "kompetensi auditor memiliki pengaruh positif terhadap kualitas audit" diterima.

\section{4) Pengaruh independensi terhadap kualitas audit}

Berdasarkan tabel uji $\mathrm{t}$ di atas diketahui bahwa nilai Sig variabel independensi adalah sebesar 0,035, dan nilai tersebut lebih kecil dari derajat kesalahan $(\alpha=0,05)(0,035<0,05)$. Hal ini berarti independensi berpengaruh signifikan terhadap kualitas audit. Dengan demikian maka hipotesis kedua (H2) yang di ajukan dalam penelitian ini di mana, "independensi auditor memiliki pengaruh positif terhadap kualitas audit" diterima. 


\section{5) Pengaruh profesionalisme terhadap kualitas audit}

Berdasarkan tabel uji $\mathrm{t}$ di atas diketahui bahwa nilai Sig variabel profesionalisme adalah sebesar 0,003, dan nilai tersebut lebih kecil dari derajat kesalahan $(\alpha=0,05)(0,003<0,05)$. Hal ini berarti profesionalisme berpengaruh signifikan terhadap kualitas audit. Dengan demikian maka hipotesis ketiga (H3) yang di ajukan dalam penelitian ini di mana, "profesionalisme auditor memiliki pengaruh positif terhadap kualitas audit" diterima.

\section{i. Hasil Uji Model 2}

Pengujian model 2 dilakukan untuk mengetahui peran etika auditor sebagai variabel moderasi dalam pengaruh kompetensi terhadap kualitas audit. Berikut akan diuraikan hasil pengujian model 1 dalam penelitian ini.

1) Uji Koefisien Determinasi Model 2

Tabel 5.15

Hasil Uji Koefisien Determinasi Model 2

\begin{tabular}{ll|r|r|r|r} 
Model & $R$ & R Square & $\begin{array}{c}\text { Adjusted R } \\
\text { Square }\end{array}$ & $\begin{array}{c}\text { Std. Error of } \\
\text { the Estimate }\end{array}$ & $\begin{array}{l}\text { Durbin- } \\
\text { Watson }\end{array}$ \\
\hline 1 &, $742^{\mathrm{a}}$ & $\mathbf{5 5 0}$ &, 531 &, 44721 & 1,883 \\
\hline
\end{tabular}

Sumber: Output SPSS, 2020

Berdasarkan tabel di atas, menunjukkan bahwa nilai koefisien determinasi (R-Square) sebesar 0,550 atau $55,0 \%$. Artinya variabel kualitas audit mampu dijelaskan oleh variabel kompetensi, etika audit, dan variabel interaksi antara kompetensi dengan etika auditor sebesar 55,0\% dan sisanya yaitu 45,0\%, dijelaskan oleh variabelvariabel lain diluar variabel pada model penelitian.

\section{2) Uji t Model 2}

Tabel 5.16

Hasil Uji t Model 2

\begin{tabular}{|c|c|c|c|c|c|c|}
\hline \multirow[b]{2}{*}{ Mode } & & \multicolumn{2}{|c|}{$\begin{array}{l}\text { Unstandardized } \\
\text { Coefficients }\end{array}$} & \multirow{2}{*}{$\begin{array}{l}\text { Standardize } \\
\mathrm{d} \\
\text { Coefficients } \\
\text { Beta }\end{array}$} & \multirow[t]{2}{*}{$\mathrm{t}$} & \multirow[t]{2}{*}{ Sig. } \\
\hline & & B & Std. Error & & & \\
\hline \multirow[t]{4}{*}{1} & (Constant) & ,448 & 1,264 & & ,354 & ,724 \\
\hline & Kompetensi & ,970 & ,401 & 1,117 & 2,422 & ,018 \\
\hline & Etika Audit & 667 & ,303 & ,588 & 2,202 & ,024 \\
\hline & $\begin{array}{l}\text { Moderasi=X1 * } \\
\text { M }\end{array}$ & ,210 & 106 & 233 & 1,998 & ,047 \\
\hline
\end{tabular}

Sumber: Output SPSS, 2019

Berdasarkan tabel di atas diketahui nilai Sig. interaksi kompetensi dan etika auditor yaitu sebesar 0,047. Nilai tersebut lebih kecil dari derajat kesalahan $\quad(\alpha=0,05) \quad(0,047<0,05)$. Dengan demikian maka dapat disimpulkan bahwa etika auditor memperkuat pengaruh kompetensi terhadap kualitas auditor. Hasil interaksi komepetensi dan etiak auditor tergolong dalam quasi moderasi, di mana kompetensi berpengaruh signifikan 
Invoice: Jurnal Ilmu Akuntansi

p-ISSN: 2714-6359 e-ISSN: 2714-6340

Vol.2 Nomor 2 September 2020

terhadap kualitas audit dan juga hasil interaksi kompetensi dengan etika auditor berpengaruh signifikan terhadap kualitas audit. Dengan demikian maka hipotesis keempat (H4) dalam penelitian ini di mana, "etika `auditor memperkuat pengaruh kompetensi terhadap kualitas audit" diterima.

\section{j. Hasil Uji Model 3}

1) Uji Koefisien Determinasi Model 3

Tabel 5.17

Hasil Uji Koefisien Determinasi Model 3

\begin{tabular}{ll|r|r|r|r} 
Model & $\mathrm{R}$ & R Square & $\begin{array}{c}\text { Adjusted } \\
\text { R Square }\end{array}$ & $\begin{array}{c}\text { Std. Error of } \\
\text { the Estimate }\end{array}$ & $\begin{array}{l}\text { Durbin- } \\
\text { Watson }\end{array}$ \\
\hline 1 &, $694^{\mathrm{a}}$ &, 482 &, 460 &, 48006 & 1,760 \\
\hline Sumber: Output SPSS, 2020 &
\end{tabular}

Sumber: Output SPSS, 2020

Berdasarkan tabel di atas, menunjukkan bahwa nilai koefisien determinasi (R-Square) sebesar 0,482 atau $48,2 \%$. Artinya variabel kualitas audit mampu dijelaskan oleh variabel independensi, etika audit, dan variabel interaksi antara independeis dengan etika auditor sebesar 48,2\% dan sisanya yaitu 51,8\%, dijelaskan oleh variabelvariabel lain diluar variabel pada model penelitian.

\section{2) Uji t Model 3}

Tabel 5.18

\section{Hasil Uji t Model 3}

\begin{tabular}{|c|c|c|c|c|c|c|}
\hline \multirow{2}{*}{\multicolumn{2}{|c|}{ Model }} & \multicolumn{2}{|c|}{$\begin{array}{l}\text { Unstandardized } \\
\text { Coefficients }\end{array}$} & \multirow{2}{*}{$\begin{array}{l}\text { Standardiz } \\
\text { ed } \\
\text { Coefficients } \\
\text { Beta }\end{array}$} & \multirow[b]{2}{*}{$\mathrm{t}$} & \multirow[b]{2}{*}{ Sig. } \\
\hline & & $\mathrm{B}$ & Std. Error & & & \\
\hline \multirow[t]{4}{*}{1} & (Constant) & 1,725 & 1,610 & & 1,071 & ,288 \\
\hline & Independensi & 1,363 & ,495 & 1,328 & 2,756 & , 007 \\
\hline & Etika Audit & ,899 & 393 & ,774 & 2,284 & 020 \\
\hline & Moderasi $=\mathrm{X} 2 * \mathrm{M}$ & ,325 & ,127 & 317 & 2,552 & ,009 \\
\hline
\end{tabular}

Sumber: Output SPSS, 2019

Berdasarkan tabel di atas diketahui nilai Sig. interaksi independensi dan etika auditor yaitu sebesar 0,009. Nilai tersebut lebih kecil dari derajat kesalahan $\quad(\alpha=0,05) \quad(0,009<0,05)$. Dengan demikian maka dapat disimpulkan bahwa etika auditor memperkuat pengaruh independensi terhadap kualitas auditor. Hasil interaksi independsi dan etika auditor tergolong dalam quasi moderasi, di mana independensi berpengaruh signifikan terhadap kualitas audit dan juga hasil interaksi independensi dengan etika auditor berpengaruh signifikan terhadap kualitas audit. Dengan demikian maka hipotesis kelima (H5) dalam penelitian ini di mana, "etika auditor memperkuat pengaruh independensi terhadap kualitas audit" diterima.

k. Hasil Uji Model 4

1) Uji Koefisien Determinasi Model 4

Tabel 5.19 


\begin{tabular}{lc|r|r|r|r}
\multicolumn{7}{c}{ Hasil Uji Koefisien Determinasi Model 4 } \\
Model & $\mathrm{R}$ & $\mathrm{R}$ Square & $\begin{array}{l}\text { Adjusted } \\
\text { R Square }\end{array}$ & $\begin{array}{c}\text { Std. Error of } \\
\text { the Estimate }\end{array}$ & $\begin{array}{l}\text { Durbin- } \\
\text { Watson }\end{array}$ \\
\hline 1 &, $636^{\mathrm{a}}$ &, 404 &, 379 &, 51495 & 1,747 \\
\hline Sumber: Output SPSS, 2020 & & &
\end{tabular}

Berdasarkan tabel di atas, menunjukkan bahwa nilai koefisien determinasi (R-Square) sebesar 0,404 atau $40,4 \%$. Artinya variabel kualitas audit mampu dijelaskan oleh variabel profesionalisme, etika audit dan variabel interaksi antara profesionalisme dengan etika auditor sebesar 40,4\% dan sisanya yaitu 59,6\%, dijelaskan oleh variabelvariabel lain diluar variabel pada model penelitian.

\section{2) Uji t Model 4}

Tabel 5.20

Hasil Uji t Model 4

\begin{tabular}{|c|c|c|c|c|c|c|}
\hline \multirow[b]{2}{*}{ Model } & & \multicolumn{2}{|c|}{$\begin{array}{l}\text { Unstandardized } \\
\text { Coefficients }\end{array}$} & \multirow{2}{*}{$\begin{array}{c}\text { Standardize } \\
\text { d } \\
\text { Coefficients } \\
\text { Beta }\end{array}$} & \multirow[t]{2}{*}{$\mathrm{t}$} & \multirow[t]{2}{*}{ Sig. } \\
\hline & & B & Std. Error & & & \\
\hline \multirow[t]{4}{*}{1} & (Constant) & 1,018 & 1,463 & & ,696 & ,489 \\
\hline & $\begin{array}{l}\text { Profesionalism } \\
\text { e }\end{array}$ & 1,050 & ,461 & 1,103 & 2,278 & ,026 \\
\hline & Etika Audit & ,849 & ,408 & ,731 & 2,089 & , 048 \\
\hline & $\begin{array}{l}\text { Moderasi=X3 * } \\
\text { M }\end{array}$ & ,169 & , 136 & ,821 & 1,246 & ,217 \\
\hline
\end{tabular}

Sumber: Output SPSS, 2019

Berdasarkan tabel di atas diketahui nilai Sig. interaksi profesionalisme dan etika auditor yaitu sebesar 0,217. Nilai tersebut lebih besar dari derajat kesalahan $\quad(\alpha=0,05) \quad(0,217>0,05)$. Dengan demikian maka dapat disimpulkan bahwa etika auditor tidak memperkuat pengaruh profesionalisme terhadap kualitas auditor. Hasil interaksi profesionalisme dan etika auditor tergolong dalam prediktor moderasi, di mana profesionalisme berpengaruh signifikan terhadap kualitas audit namun hasil interaksi profesionalisme dengan etika auditor tidak berpengaruh terhadap kualitas audit. Dengan demikian maka hipotesis keenam (H6) dalam penelitian ini di mana, "etika auditor memperkuat pengaruh profesionalisme terhadap kualitas audit" ditolak.

\subsection{Pembahasan}

\section{a. Pengaruh Kompetensi Auditor Terhadap Kualitas Audit}

Kompetensi auditor adalah auditor yang dengan pengetahuan, pengalaman, pendidikan dan pelatihan yang memadai dan dapat melakukan audit secara objektif dan cermat. Kualitas audit merupakan segala kemungkinan dimana auditor pada saat mengaudit laporan keuangan klien dapat menemukan pelanggaran yang terjadi dalam sistem akuntansi klien dan melaporkannya dalam laporan keuangan audit, dimana 
dalam melaksanakan tugasnya tersebut auditor harus berpedoman pada standar auditing. Dalam melaksanakan proses audit, auditor membutuhkan pengetahuan, pengalaman, pendidikan dan pelatihan yang baik karena dengan hal itu auditor menjadi lebih mampu memahami kondisi keuangan dan laporan keuangan kliennya dan akan menghasilkan kualitas yang baik.

Berdasarkan hasil penelitian diketahui bahwa kompetensi memiliki koefisien positif terhadap kualitas audit. Hal ini menunjukkan bahwa kompetensi memiliki pengaruh yang searah terhadap kualitas audit. Kompetensi merupakan faktor pendukung kualitas hasil audit. Dengan kata lain, semakin auditor berkompeten maka akan berdampak pada semakin baik kualitas hasil audit. Hasil penelitian ini didukung oleh Tubbs (1990) dalam Ayuningtyas (2012), yang menyatakan bahwa dalam mendeteksi sebuah kesalahan, seorang auditor harus didukung dengan pengetahuan tentang apa dan bagaimana kesalahan tersebut terjadi.

Sementara itu, berdasarkan hasil uji parsial diketahui bahwa kompetnesi terbukti berpengaruh signifikan terhadap kualitas audit. Hal ini berarti kompetensi merupakan faktor penentu berkualitas dan tidaknya hasil audit. Dilihat dari latar belakang tingkat pendidikan auditor di lingkungan Inspektorat Provinsi Sulawesi Barat jumlah auditor Strata 1 (S1) sebesar 69,3\%, dan Strata 2 (S2) sebesar 30,7\% dapat dikatakan bahwa sudah banyak auditor mempunyai tingkat pendidikan yang tinggi dan mempunyai pengetahuan dan wawasan yang luas. Dengan demikian maka kompetensi auditor dapat memberikan kontribusi yang berarti terhadap kualitas audit.
Hasil penelitian ini sama dengan hasil penelitian yang dilakukan oleh Hapsari (2007), Hidayat (2011), Rukhaidah (2010), Apriyanto (2012), Widodo (2012), Nurjannah, dkk (2016) dan Latrini, dkk (2016) yang menemukan bahwa kompetensi berpengaruh positif dan signifikan terhadap kualitas audit.

\section{b. Pengaruh Independensi Auditor Terhadap Kualitas Audit}

Independensi merupakan sikap yang harus dimiliki oleh auditor untuk tidak memiliki kepentingan pribadi dalam melaksanakan tugasnya karena dengan posisi auditor yang independen banyak menimbulkan dilematis baginya yang dapat melanggar standar profesi sebagai acuan dalam melakukan tugasnya. Profesi auditor yang independen, apabila seorang auditor memiliki cara pandang yang tidak memihak siapapun dalam pelaksanaan pengujian evaluasi hasil pemeriksaan dan penyusunan laporan audit. Hal ini, harus dilakukan oleh auditor dengan tujuan agar menambah kredibilitas laporan yang disajikan oleh manajemen, karena bila auditor tidak bersikap independen maka kualitas hasil audit tidak baik, sehingga opini yang dihasilkan auditor tidak dapat memberikan tambahan yang berguna bagi klien.

Berdasarkan hasil penelitian diketahui bahwa independensi memiliki koefisien positif terhadap kualitas audit. Hal ini menunjukkan bahwa independensi memiliki pengaruh yang searah terhadap kualitas audit. Independensi merupakan faktor pendukung kualitas hasil audit. Dengan kata lain, semakin auditor bersikap independen maka akan berdampak pada 
semakin baik kualitas hasil audit. Hasil penelitian ini mendukung agency theory, bahwa seorang auditor yang independent di dapat membantu konflik yang terjadi antara principal (rakyat) dan agent (pemerintah). Di mana principal selaku pemberi mandat kepada pemerintah untuk mengoperasikan keuangannya dan pemerintah mempertanggungjawabakan hal itu dengan membuat laporan keuangan berdasarkan kenyataan yang realible. Dengan adanya auditor yang independen dapat mengevaluasi kinerja manajemen sehingga dapat mendeteksi ada tidaknya kecurangan.

Selain itu, hasil penelitian ini juga mendukung Theory of Attitude and Behaviour yang dikembangkan oleh Triadis (1971) dalam Putri (2011), yang menjelaskan tentang sikap seseorang yang dapat mempengaruhi perilaku orang tersebut. Dalam hal ini, seorang orang auditor yang memiliki sikap independensi yang tinggi, maka ia akan berperilaku independen dalam menjalankan tugasnya. Teori ini berusaha menjelaskan mengenai aspek perilaku manusia dalam suatu organisasi khususnya auditor yang mengalami hambatan - hambatan yang dapat mengancam sikapa independensi dan obyektivitas selama proses audit.

Sementara itu, berdasarkan hasil uji parsial diketahui bahwa independensi terbukti berpengaruh signifikan terhadap kualitas audit. Hal ini berarti independensi merupakan faktor penentu berkualitas dan tidaknya hasil audit. Auditor yang mempertahankan sikap independensi, maka kualitas audit yang dihasilkan akan semakin baik. Semakin auditor mampu menjaga independensinya dalam menjalankan penugasan profesionalnya maka kualitas audit yang dihasilkan akan meningkat.

Hasil penelitian ini sejalan dengan hasil penelitian sebelumnya dari Rukhaidah (2010), Hidayat (2011), Widodo (2012), Nurjannah, dkk (2016) dan Tawakkal, dkk (2019), yang menemukan bahwa independensi berpengaruh positif dan signifikan terhadap kualitas audit.

\section{c. Pengaruh Profesionalisme Auditor Terhadap Kualitas Audit}

Profesionalisme juga merupakan syarat utama sebagai auditor. profesionalisme auditor mengacu pada kemampuan dan perilaku profesional. Kemampuan didefinisikan sebagai pengetahuan, pengalaman, kemampuan teknologi, dan memungkinkan perilaku profesional auditor untuk mencakup faktor-faktor tambahan seperti transparansi dan tanggung jawab, hal ini sangat penting untuk memastikan kepercayaan publik. Profesionalisme adalah salah satu nilai-nilai dasar BPK yang merupakan kode etik bagi auditor BPK. Pekerjaan audit yang dikerjakan dengan profesionalisme akan memberi hasil audit yang dapat diandalkan dan dipercaya oleh publik.

Berdasarkan hasil penelitian diketahui bahwa profesionalisme memiliki koefisien positif terhadap kualitas audit. Hal ini menunjukkan bahwa profesionalisme memiliki pengaruh yang searah terhadap kualitas audit. Profesionalisme merupakan faktor pendukung kualitas hasil audit. Dengan kata lain, semakin auditor bersikap profesional maka akan berdampak pada semakin baik kualitas hasil audit. Hasil penelitian ini mendukung theory of planned behaviour (Khreshastuti, 2014), bahwa profesional merepresentasikan 
sikap dalam dalam konsep teori perilaku terencana. Sikap adalah keadaan dalam diri manusia yang dapat menggerakkan manusia untuk bertindak atau tidak bertindak. Salah satu sikap seorang auditor untuk menunjukkan profesionalismenya adalah melalui kepatuhan terhadap standar audit dan kode etik profesi auditor yang diatur dalam Standar Profesional Akuntan Publik dan Kode Etik Profesi Akuntan Publik. Standar audit dan kode etik atau aturan perilaku dibuat untuk dipedomani dalam berperilaku terutama dalam melaksanakan penugasan demi menjaga mutu pekerjaan auditor, sehingga dapat menumbuhkan kepercayaan dan memelihara citra organisasi di mata masyarakat.

Sementara itu, berdasarkan hasil uji parsial diketahui bahwa profesionalisme terbukti berpengaruh signifikan terhadap kualitas audit. Hal ini berarti profesionalisme merupakan faktor penentu berkualitas dan tidaknya hasil audit. Selain memelihara kepercayaan publik dan melayani kepentingan publik, auditor BPKP juga memiliki tanggung jawab yang penting dalam melakukan audit, yaitu mempertahankan profesionalismenya. Auditor BPKP harus bersikap profesional dalam melakukan pekerjaan auditnya. Auditor BPKP harus memiliki sikap untuk melayani kepentingan publik, menghargai dan memelihara kepercayaan publik, dan mempertahankan profesionalisme (SPKN).

Hasil penelitian ini mendukung hasil penelitian sebelumnya dari Nasrah (2011) dan Junaidi, dkk (2017) yang menemukan bahwa profesionalisme berpengaruh positif dan signifikan terhadap kualitas audit.

\section{d. Pengaruh Kompetensi Terhadap Kualitas Audit dengan Etika Audit sebagai Variabel Modarasi}

Etika auditor berpengaruh signifikan dan memperkuat hubungan kompetensi dengan kualitas audit. Benh, dkk (1997) dalam Darayasa dan Wisadha (2016), mengembangkan atribut kualitas audit yang salah satu di antaranya adalah standar etika yang tinggi, sedangkan atribut - atribut lainnya terkait dengan kompetensi auditor. Audit yang berkualitas sangat penting untuk menjamin bahwa profesi akuntan memenuhi tanggungjawabnya kepada investor, masyarakat umum dan pemerintah serta pihak - pihak lain yang mengandalkan kredibilitas laporan keuangan yang telah diaudit, dengan menegakkan etika yang tinggi.

Adanya kesadaran akan etika auditor dalam bekerja akan menambah kompetensi seorang auditor dalam melakukan pekerjaanya, sehingga akan menghasilkan suatu kualitas audit yang berkualitas baik (Tritamas dan Astika, 2018). Semakin tinggi auditor mentaati etika auditor maka kualitas audit yang dihasilkan akan semakin tinggi. Namun semakin rendah auditor mentaati etika auditor maka kualitas yang dihasilkan semakin rendah. Semakin baik kompetensi yang dimiliki oleh auditor maka kualitas audit yang dihasilkan akan semakin berkualitas. Namun semakin rendah kompetensi yang dimiliki oleh auditor maka kualitas yang dihasilkan semakin rendah. Sehingga kompetensi dan etika auditor dapat mempengaruhi kualitas audit yang dihasilkan tergantung dari situasi yang dialami oleh seorang auditor dalam melakukan audit (Harjanto, 2014).

Hasil penelitian ini mendukung hasil penelitian sebelumnya dari 
Wicaksono (2015), dan Tritamas dan Astika (2018), yang menemukan bahwa etika auditor memoderasi pengaruh kompetensi secara positif terhadap kualitas audit. Hasil ini menunjukkan bahwa adanya etika auditor yang baik semakin memperkuat pengaruh kompetensi terhadap kualitas audit.

\section{e. Pengaruh Independensi Terhadap Kualitas Audit dengan Etika Audit sebagai Variabel Modarasi}

Auditor dalam melaksanakan tugasnya harus didukung dengan kemampuan dalam mengumpulkan setiap informasi yang dibutuhkan guna mengambil keputusan audit. Namun demikian, kompetensi seorang auditor harus juga didukung oleh dimana hal tersebut harus didukung dengan sikap independen. Tidak dapat dipungkiri bahwa sikap independen merupakan hal yang melekat pada diri auditor, sehingga independen seperti telah menjadi syarat mutlak yang harus dimiliki.

Etika auditor berpengaruh signifikan dan memperkuat hubungan independensi dengan kualitas audit. Penelitian Nichols dan Price (1976) dalam Darayasa dan Wisadha (2016), menemukan bahwa ketika auditor dan manajemen tidak mencapai kata sepakat dalam aspek kinerja, maka kondisi ini dapat mendorong manajemen untuk memaksa auditor melakukan tindakan yang melawan standar, termasuk dalam pemberian opini. Kondisi ini akan sangat menyudutkan auditor sehingga ada kemungkinan bahwa auditor akan melakukan apa yang diinginkan oleh pihak manajemen.

Etika auditor memperkuat pengaruh independensi pada kualitas audit. Seorang auditor untuk menjaga kualitas audit yang baik harus berprilaku independen, karena indpendensi merupakan syarat mutlak yang harus dimiliki seorang auditor (Tritamas dan Astika, 2018). Penelitian Nichols dan Price (1976) dalam Ismiyati (2019), menemukan bahwa ketika auditor dan manajemen tidak mencapai kata sepakat dalam aspek kinerja, maka kondisi ini dapat mendorong manajemen untuk memaksa auditor melakukan tindakan yang melawan standar, termasuk dalam pemberian opini. Kondisi ini akan sangat menyudutkan auditor sehingga ada kemungkinan bahwa auditor akan melakukan apa yang diinginkan oleh pihak manajemen. Sedangkan Deid dan Giroux (1992) dalam Ismiyati (2019), mengatakan bahwa pada konflik kekuatan, klien dapat menekan auditor untuk melawan standar professional dan dalam ukuran yang besaran kondisi keuangan klien yang sehat dapat digunakan sebagai alat untuk menekan auditor dengan cara melakukan pergantian auditor.

Hal ini dapat membuat auditor tidak akan dapat bertahan dengan tekanan klien tersebut sehingga menyebabkan indepedensi mereka melemah. Posisi auditor juga sangat dilematis dimana mereka dituntut untuk memenuhi keinginan klien namun disatu sisi tindakan auditor dapat melanggar standar profesi sebagai acuan kerja mereka dalam penelitan mereka terdapat argumen bahwa kemampuan auditor untuk dapat bertahan di bawah tekanan klien mereka tergantung dari kesepakatan ekonomi, lingkungan tertentu, dan perilaku di dalamnya mencangkup etika professional. Apabila seorang auditor telah melawan standar profesional yang telah ditetapkan, maka kualitas audit yang dihasilkan oleh auditor akan sangat rendah. Namun 
semakin tinggi auditor mentaati etika auditor maka kualitas audit yang dihasilkan akan semakin tinggi. Semakin rendah mentaati etika auditor maka kualitas audit yang dihasilkan akan semakin rendah. semakin tinggi independensi auditor maka kualitas audit yang dihasilkan akan semakin tinggi. Semakin rendah independensi auditor maka kualitas audit yang dihasilkan akan semakin rendah Sehingga hubungan antara independensi dan etika auditor dapat mempengaruh kualitas audit yang dihasilkan tergantung dari situasi yang dialami oleh seorang auditor dalam melakukan audit.

Hasil penelitian ini mendukung hasil penelitian sebelumnya dari Wicaksono (2015), yang menemukan bahwa etika auditor memoderasi pengaruh independensi secara positif terhadap kualitas audit Hasil ini menunjukkan bahwa adanya etika auditor yang baik semakin memperkuat pengaruh independensi terhadap kualitas audit yang dihasilkan.

\section{f. Pengaruh Profesionalisme Terhadap Kualitas Audit dengan Etika Audit sebagai Variabel Modarasi}

Etika berkaitan dengan pertanyaan tentang bagaimana orang akan berperilaku terhadap sesamanya. Etika Auditor adalah bagaimana auditor berperilaku terhadap sesamanya. Penelitian ini menguji etika auditor sebagai variabel moderasi dalam hubungan kompetensi, independendan profesionalisme dengan kualitas audit.

Etika auditor dalam penelitian ini tidak memperkuat pengaruh profesionalisme terhadap kualitas audit. Hal ini sesuai dengan penjelasan dari Giroux (1992) dalam Karnisa (2015) mengatakan bahwa pada konflik kekuatan, klien dapat menekan auditor untuk melawan standar profesional dan dalam ukuran yang besaran kondisi keuangan klien yang sehat dapat digunakan sebagai alat untuk menekan auditor dengan cara melakukan melakukan pergantian auditor. Hal ini dapat membuat auditor tidak akan dapat bertahan dengan tekanan klien tersebut sehingga menyebabkan independensi mereka melemah. Posisi auditor juga sangat dilematis dimana mereka dituntut untuk memenuhi keinginan klien namun disatu sisi tindakan auditor dapat melanggar standar profesi sebagai acuan kerja mereka.

Hasil penelitian ini juga mendukung hasil penelitian Suharti (2017) yang menemukan bahwa etika auditor tidak mampu memoderasi pengaruh profesionalisme dan independensi terhadap kualitas audit.

\section{PENUTUP}

\subsection{Simpulan}

Berdasarkan hasil penelitian dan pembahasan pada bab sebelumnya maka simpulan penelitian ini adalah sebagai berikut:

1. Kompetensi auditor berpengaruh positif dan signifikan terhadap Kualitas Audit di Badan Pengawasan Keuangan dan Pembangunan Perwakilan Provinsi Sulawesi Barat.

2. Independensi auditor berpengaruh positif dan signifikan terhadap kualitas audit di Badan Pengawasan Keuangan dan Pembangunan Perwakilan Provinsi Sulawesi Barat.

3. Profesionalisme auditor berpengaruh positif dan signifikan terhadap kualitas audit di Badan Pengawasan Keuangan dan Pembangunan Perwakilan Provinsi Sulawesi Barat. 
4. Etika auditor mampu memoderasi pengaruh kompetensi terhadap kualitas audit di Badan Pengawasan Keuangan dan Pembangunan Perwakilan Provinsi Sulawesi Barat.

5. Etika auditor mampu memoderasi pengaruh independensi terhadap kualitas audit di Badan Pengawasan Keuangan dan Pembangunan Perwakilan Provinsi Sulawesi Barat.

6. Etika auditor tidak mampu memoderasi pengaruh profesionalisme terhadap kualitas audit di Badan Pengawasan Keuangan dan Pembangunan Perwakilan Provinsi Sulawesi Barat.

\subsection{Saran}

Berdasarkan simpulan penelitian maka saran yang diberikan dari penelitian ini adalah sebagai berikut:

1. Kepada Auditor di Badan Pengawasan Keuangan dan Pembangunan Perwakilan Provinsi Sulawesi Barat diharapkan dapat berkomitmen terhadap etika profesi auditor. Karena etika auditor yang kurang akan melemahkan kompetensi, independensi dan profesionalisme.

2. Kepada peneliti selanjutnya, disarankan untuk menambahkan faktor - faktor lain sebagai variabel yang dapat mempengaruhi kualitas audit seperti tekanan anggaran waktu, integritas dan obyektivitas. Selain itu, obyek penelitian ini hanya sebatas pada Badan Pengawasan Keuangan dan Pembangunan Perwakilan Provinsi Sulawesi Barat, disarankan untuk peneliti selanjutnya memperluas lingkup yang dijadikan obyek penelitian.

\section{DAFTAR PUSTAKA}

Abadi Yusuf, Amir. 2012. Audit Pendekatan Terpadu.Edisi Revisi. Salemba Empat. Jakarta.

Agoes, Sukrisno. 2013. Auditing Petunjuk Praktis pemeriksaan Akuntan oleh Akuntan Publik Edisi 4 Buku 1. Jakarta: Salemba Empat.

Agusti, Restu dan Nastia Putri P. 2013. Pengaruh Kompetensi, Independensi dan Profesionalisme Terhadap Kualitas Audit (Studi Empiris Pada Kantor Akuntan Publik Semarang). Riau. Universitas Riau. Jurnal Ekonomi Vol.21, No.3 (Sep).

Amin Widjaja Tunggal. (2013). Pokok Pokok Auditing dan Jasa Asurans. Jakarta. Harvindo.

Anugerah, Rita, dan Sony Harsono Akbar. 2014. Pengaruh kompetensi, kompleksitas tugas dan skeptisme profesional terhadap kualitas audit. Jurnal Akuntansi. Vol.2, No.2. Hal: 139-148.

Arens, Alvin A., et al. 2011. Auditing dan Jasa Assurance. Jakarta: Erlangga.

Arens A., Randal J. Elder, Mark S, Beasley. 2012. Auditing And Assurance Services: An Integrated Approach14th edition. New Jersey: Prentice-Hall.

Arens, Alvin. A, Randal J. Elder, Mark S. Beasleydan Jusuf, Amir. 2013. Jasa Audit dan Assurance Pendekatan Terpadu

(Adaptasi Indonesia).Jakarta: Salemba Empat.

Ayuningtyas, Harvita Yulian. 2012. Pengaruh Pengalaman Kerja, Independensi, Obyektifitas, Integritas Dan Kompetensi Terhadap Kualitas Hasil Audit (Studi Kasus Pada Auditor Inspektorat Kota/Kabupaten di Jawa Tengah). Diponegoro Journal of Accounting. Vol. 1, No. 2, Tahun 2012. 
Badan Pengawasan Keuangan dan Pembangunan. 2007. Akuntabilitas Instansi Pemerintah. Jakarta.

Bambang Supomo dan Nur Indriantoro, 2002, Metodologi Penelitian Bisnis, Cetakan Kedua, Yogyakara; Penerbit BFEE UGM.

Bedard, Jean dan Michelene Chi T. H. 1993. Expertise in Auditing.Journal of Accounting Practice \& Theory 12: 21-45.

Castellani, Justinia., (2008) Kompetensi dan Independensi Auditor Pengaruhnya pada Kualitas Audit, Trikonomika, Vol 7, No. 2, Desember 2008:114:121.

Christiawan, Yulius Jogi. (2002). Pengaruh Kompetensi dan Independensi terhadap Kelangsungan Usaha Kantor Akuntan Publik (KAP) di Surabaya. Jurnal Akuntansi dan Keuangan Vol.4 No. 2.

Christiawan, Yulius Jogi. 2003. Kompetensi dan Independensi Akuntan Publik: Refleksi Hasil Penelitian Empiris. Jurnal Akuntansi dan Keuangan. Vol.4 No. 2 (Nov) hal. 79-92.

Darayasa, I Made., dan I Gede Supartha Wisadha. 2016. Etika Auditor Sebagai Pemoderasi Pengaruh Kompetensi dan Independensi Pada Kualitas Audit di Kota Denpasar. E jurnal Akuntansi Universitas Udayana. Vol. 15, No. 1, April (2016).

De Angelo. 1981. Auditor Independence, "Low Balling", and Disclosure Regulation.Journal of Accounting and Economics 3. August.

Degibson Siagian, Sugiarto. (2000). Metode Statistika Untuk Ekonomi dan Bisnis. Jakarta: Gramedia.

Ditia Ayu dan Chariri Anis 2015. Pengaruh Kompetensi dan Independensi Terhadap Kualitas
Audit dengan Motivasi dan Etika Auditor sebagai Variabel Moderasi (Studi Empiris Pada Kantor Akuntan Publik di Jakarta) Diponegoro Journal Of Economics, Volume 4, ISSN: 2337-3814.

Futri, Septiani Putu. Juliarsa Gede. 2014. Pengaruh Independensi, Profesionalisme, Tingkat Pendidikan, Etika Profesi, Pengalaman, Dan Kepuasan Kerja Auditor Pada Kualitas Audit Kantor Akuntan Publik Di Bali.E-Jurnal Akuntansi Universitas Udayana 7.2 (2014): 444-461.

Ghozali, Imam. 2001. Aplikasi Analisis Multivariate Dengan Program SPSS. Edisi Kedua.Semarang: Badan Penerbit Universitas Diponegoro.

Ghozali, Imam. 2005. Aplikasi Analisis Multivariate dengan SPSS. Semarang: Badan Penerbit UNDIP.

Ghozali, Imam. 2006. Aplikasi Analisis Multivariate Dengan Program SPSS. CetakanKeempat. Semarang: Badan Penerbit Universitas Diponegoro.

Herawati dan Susanto. 2009. Pengaruh Profesionalisme,

PengetahuanMendeteksi Kekeliruan dan Etika Profesi terhadap Pertimbangan TingkatMaterialitas Akuntan Publik. Jurnal Akuntansi dan KeuanganVol.11No.1.

Indah, Siti NurMawar. 2010. Pengaruh Kompetensi dan Independensi Auditor Terhadap Kualitas Audit. Jurnal

Fakultas EkonomiUniversitas Diponegoro Semarang.

Indriantoro, Nur, dan Bambang Supomo, 1999, Metodologi Penelitian dan Bisnis, Yogyakarta: BPFE Yogyakarta.

Institute Akuntan Publik Indonesia. 2008. Kode Etik Profesi Akuntan Publik. Dikeluarkan oleh Dewan Standar Profesi Akuntan Publik Institut Akuntan Publik Indonesia. 
Ismiyati, Anna Anica. 2019. Pengaruh Kompetensi, Independensi, Dan Akuntabilitas Terhadap Kualitas Audit Dengan Etika Auditor Sebagai Variabel Moderasi (Studi Empiris pada Kantor Akuntan Publik di Provinsi Banten). Jurnal Riset Akuntansi Tirtayasa, Vol. 04 No. 01 April 2019

Jensen \& Meckling, 1976, The Theory of The Firm: Manajerial Behaviour, Agency Cost, and Ownership Structure, Journal of Financial and Economics, 3:305-360.

Karnisa, Ditia Ayu. 2015. Pengaruh Kompetensi dan Independensi Terhadap Kualitas Audit dengan Motivasi dan Etika Auditor sebagai Variabel Moderasi (Studi Empiris Pada Kantor Akuntan Publik di Jakarta). Diponegoro Journal of Econmics, Vol. 4, No. 2. Tahun 2015

Kreshastuti, Destriana Kurnia. 2014. Analisis Faktor - Faktor yang Memengaruhi Intensi Auditor untuk Melakukan Tindakan Whistleblowing (Studi Empiris pada Kantor Akuntan Publik di Semarang). Diponegoro Journal of Accounting. Volume 3, Nomor 2, Tahun 2014

KeputusanKepala BKN No. 46A Tahun 2003 tentang Pedoman Penyusunan Standar Kompetensi Jabatan Struktural Pegawai Negeri Sipil.

Kristanti, Stephani Widhi 2013. Identifying Illocutionary ForceOf The Host's Speech Act InMata NajwaTalk Show. Kuasa Gono Gini June 6Th, 2012 Chapter.

Komite SPAP Ikatan Akuntan Indonesia (IAI), (2001), Standar Profesional Akuntan Publik. Jakarta: Salemba Empat.

Leni, Ade Fatma Dan Firman Syarif. 2015. Faktor-Faktor Yang Mempengaruhi Kualitas Audit Dengan Etika Auditor Sebagai Moderating
Variabel. Jurnal Riset Akuntansi Dan Bisnis Volume 15 No.1.

Mardiasmo, 2002. Otonomi dan Manajemen Keuangan Daerah. Penerbit Andi Yogyakarta.

Mulyadi. 2010. Auditing.Edisi Kenam. Buku 1. Jakarta: Salemba Empat.

Nugrahini, Putri.2015. Pengaruh kompetensi dan profesionalisme auditor Internal terhadap kualitas audit (Studi Empiris pada BUMN dan BUMD di 133 Kota Yogyakarta). Skripsi. Universitas Negeri Yogyakarta.

Parasayu, Annisa dan Rohman. 2014. "Analisis Faktor-faktor yang mempengaruhiKualias Hasil Audit Internal Studi Persepsi Aparat Intern Pemerintah Kota Surakarta dan Kabupaten Boyolali". Diponegoro Journal of Accounting $3(2): 1-10$.

Priyatno, Duwi, Mandiri 3Belajar Analisis Data Dengan SPSS, Yogyakarta, Mediakom, 2013.

Rana, Sentika. 2011. Pengaruh Independensi Dan Kompetensi Terhadap Kualitas Audit yang Dilaporkan.

Sekaran, Uma (2003), Research Methods For Business: A Skill Building Aproach, New York-USA: John Wiley and Sons, Inc.

Sugiyono. 2005. Memahami Penelitian Kualitatif. Bandung: CV. Alfabeta.

Suharti. 2017. Pengaruh Pengalaman Kerja, Profesionalisme, Integritas Dan Independensi Terhadap Kualitas Audit: Etika Auditor Sebagai Variabel Pemoderasi (Studi Pada Perwakilan BPKP Provinsi Riau). KURS. Jurnal Akuntansi, Kewirausahaan dan Bisnis, Vol. 2, No. 1 (2017)

Sunyoto, Suyanto 2011. Analisis regresi untuk uji hipotesis, Yogyakarta. Caps. 
Sutton, S. G. 1993. Toward an Understanding of The factors Affecting the Quality of The Audit Process. Decission Sciences. Vol. 24:88 -105.

Tri, Patricia Diana Paramita dan Agus Suprijanto. 2018. Pengaruh Kompetensi Dan Independensi Terhadap Kualitas Audit Dengan Etika Audiotr Sebagai Variabel Moderating Studi Pada Akuntan Publik Di Kota Semarang. Journal Of Accounting Vol.21.

Triandis, H. C. (1980). Values, Attitudes, and Interpersonal Behavior. In University of Nebraska (Lincoln campus). Dept. of Psychology. (Ed.), Nebraska Symposium on Motivation (pp. 196-259). [Lincoln, Neb.]: University of Nebraska Press.

Tuanakotta, Theodorus M. 2011. Berpikir Kritis dalam Auditing. Jakarta: Salemba Empat.

Tirtamas Wisnu Wardhani, A. A. I., dan Ida Bagus Putra Astika. 2018. Pengaruh Kompetensi, Akuntabilitas Dan Independensi Pada Kualitas Audit Dengan Etika Auditor Sebagai Variabel Moderasi (Studi Kasus Pada KAP Bali). Ejurnal Akuntansi, Universitas Udayana, Vol. 23, No. 1 (2018).

Undang-Undang Nomor 23 Tahun 2014 Tentang Pemerintahan Daerah.

Wibowo, Arie dan Rossieta, Hilda. 2009. "Faktor-Faktor Determinasi Kualitas Audit-Suatu Studi dengan Pendekatan Earning Surprise Benchmark". Simposium nasional Akuntansi XII, Palembang, hal. 134.

Wicaksono, Monot. 2015. Pengaruh Kompetensi Dan Independensi Terhadap Kualitas Audit Dengan
Etika Auditor Sebagai Variabel

Pemoderasi Pada Bawasda

Pemerintah Daerah Di

ExKaresidenan Surakarta Provinsi Jawa Tengah. Jurnal Akuntansi Dan Pajak Vol. 15

Yogi, Ni Putu Sri Harta Mimba, A.A.N.B. Dwirandra. $2016 . \quad$ Etika Memoderasi Pengaruh Kompetensi, Pengalaman Dan Independensi Pada Kualitas Hasil Pemeriksaan Inspektorat E-Jurnal Ekonomi dan Bisnis 